DIW BERLIN

Discussion Papers

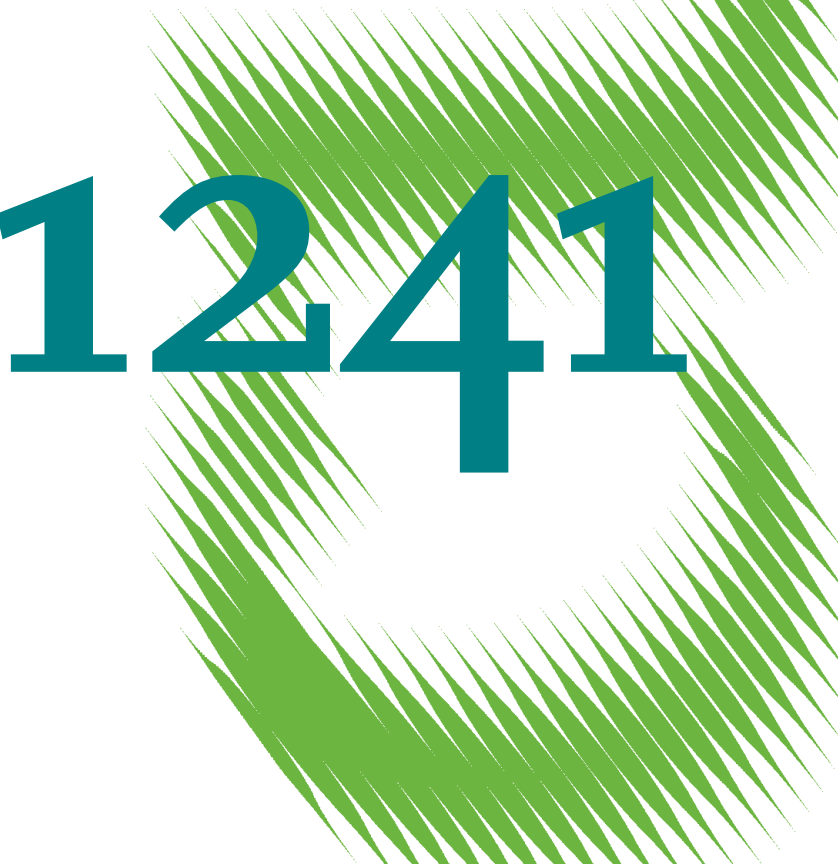

The Returns to Education for

Opportunity Entrepreneurs,

Necessity Entrepreneurs,

and Paid Employees 
Opinions expressed in this paper are those of the author(s) and do not necessarily reflect views of the institute.

IMPRESSUM

(C) DIW Berlin, 2012

DIW Berlin

German Institute for Economic Research

Mohrenstr. 58

10117 Berlin

Tel. $+49(30) 89789-0$

Fax +49 (30) $89789-200$

http://www.diw.de

ISSN print edition $1433-0210$

ISSN electronic edition 1619-4535

Papers can be downloaded free of charge from the DIW Berlin website:

http://www.diw.de/discussionpapers

Discussion Papers of DIW Berlin are indexed in RePEc and SSRN:

http://ideas.repec.org/s/diw/diwwpp.html

http://www.ssrn.com/link/DIW-Berlin-German-Inst-Econ-Res.html 


\title{
The returns to education for opportunity entrepreneurs, necessity
}

\section{entrepreneurs, and paid employees ${ }^{1}$}

\author{
Frank M. Fossen ${ }^{2} \quad$ Tobias J. M. Büttner ${ }^{3}$
}

August 21, 2012

\begin{abstract}
:
We assess the relevance of formal education for the productivity of the self-employed and distinguish between opportunity entrepreneurs, who voluntarily pursue a business opportunity, and necessity entrepreneurs, who lack alternative employment options. We expect differences in the returns to education between these groups because of different levels of control. We use the German Socio-economic Panel and account for the endogeneity of education and non-random selection. The results indicate that the returns to a year of education for opportunity entrepreneurs are 3.5 percentage points higher than the paid employees’ rate of $8.1 \%$, but 6.5 percentage points lower for necessity entrepreneurs.
\end{abstract}

JEL classification: J23, J24, J31, I20, L26

Keywords: returns to education, opportunity, necessity, entrepreneurship

\footnotetext{
${ }^{1}$ Acknowledgement: We would like to thank participants at the 2012 Tenth International German SocioEconomic Panel User Conference in Berlin and the 2011 Entrepreneurship and Public Policy Seminar at Freie Universität Berlin for valuable comments.

${ }^{2}$ Freie Universität Berlin, DIW Berlin and IZA. Corresponding author, address: Freie Universität Berlin, Boltzmannstr. 20, 14195 Berlin, Germany, phone: +49 30838 52510, fax: +49 308384 52510, e-mail: frank.fossen@fu-berlin.de.

${ }^{3}$ Technische Universität Berlin and Federal Office for Migration and Refugees, Nuremberg, Germany.
} 



\section{Introduction}

While estimating the returns to education for wage workers is consistently of the most prominent topics in labour economics, only recently have researchers attempted to assess how the returns to education compare for entrepreneurs (see Van der Sluis et al., 2008, for a survey). The research frontier concerning entrepreneurs is now taking into account the econometric challenges known from the literature concerning paid employees, such as the endogeneity of education and self-selection. These studies estimate that the returns to education are higher for entrepreneurs than for employees in the United States (Van Praag et al., 2009) and potentially also in the Netherlands (Parker and Van Praag, 2006; although these authors do not offer a direct comparison between the groups).

Entrepreneurs are a heterogeneous group, primarily because of large differences in their motivations to become entrepreneurs - you may think of the worlds between a street-food vendor and the creator of a high-tech start-up. Research in the economics of entrepreneurship distinguishes between opportunity entrepreneurs, who voluntarily engage in entrepreneurship to pursue a business opportunity they spotted, and necessity entrepreneurs, who are pushed into entrepreneurship because they lack employment alternatives (e.g. Reynolds et al., 2002; Sternberg et al., 2006; Ardagna and Lusardi, 2009; Block and Wagner, 2010). Figure 1 depicts the share of entrepreneurial activity that is necessity-driven in Germany and the US based on data from the Global Entrepreneurship Research Association (2012) and clearly indicates that this phenomenon deserves attention. Strikingly, in the US necessity entrepreneurship temporarily tripled between 2008 and 2010, presumably because of the large number of people who lost their jobs during the financial and economic crisis. ${ }^{4}$ This paper is the first to extend the emerging literature about entrepreneurs' returns to education, which

\footnotetext{
${ }^{4}$ In a New York Times article, former US Secretary of Labor Robert Reich (2010) refers to the seemingly paradoxical phenomenon of an increasing number of start-ups in the midst of the crisis and concludes that "millions of Americans had no choice but to try selling themselves".
} 
treats the entrepreneurs as a homogenous group, by investigating the heterogeneity in these returns between opportunity and necessity entrepreneurs and comparing them to those of paid employees.

Figure 1: Relative prevalence of necessity-driven entrepreneurial activity (in \%)

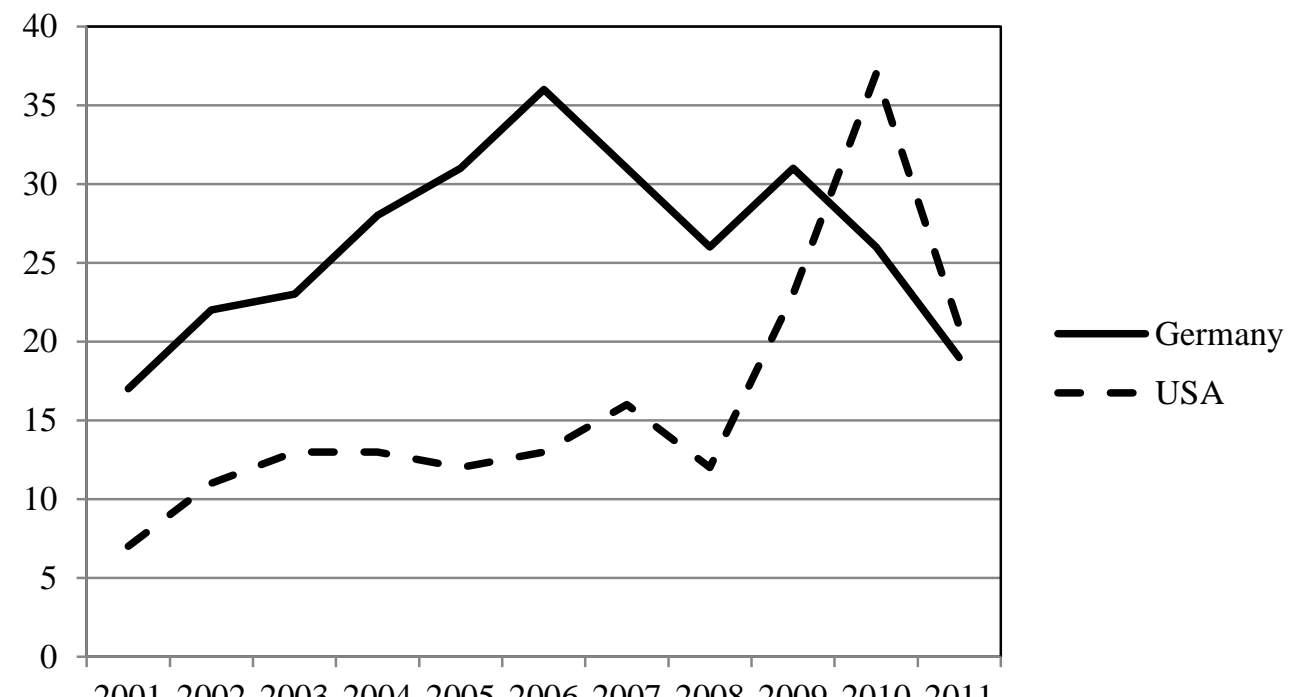

20012002200320042005200620072008200920102011

Source: Own illustration based on data from the Global Entrepreneurship Research Association (2012). Data collection started in 2001.

There is increasing evidence that the social benefits of entrepreneurship as a whole are greater than the private benefits, mainly because of its function in innovation and job creation (Van Praag and Versloot, 2007). ${ }^{5}$ Because of these presumed positive external effects, policy makers are interested in promoting entrepreneurship. This analysis focuses on education, which is known to be a central factor for productivity in modern economies. If formal education increases entrepreneurial returns relative to an employee's returns, education policy may be a suitable instrument to stimulate entrepreneurship.

To derive policy implications from estimates of entrepreneurial returns to education, one has to differentiate between opportunity and necessity entrepreneurs. Opportunity entrepreneurs are considerably more likely to generate positive external effects through

\footnotetext{
${ }^{5}$ Analysing an endogenous growth model, Michelacci (2002) provides theoretical reasons for encouraging entrepreneurship to promote innovation and growth.
} 
innovation than necessity entrepreneurs, who usually engage in conventional and established activities. Since the extant literature only estimates the returns to education averaged over opportunity and necessity entrepreneurs, it is not possible to infer if more education will make opportunity entrepreneurship more attractive than regular employment, which would likely increase its incidence. For opportunity entrepreneurs, potential income as a paid employee reflects the opportunity cost, whereas for necessity entrepreneurs, the alternative option of paid employment is at least temporarily unavailable. Therefore, for opportunity entrepreneurs, the difference in the returns to education between opportunity entrepreneurs and paid employees is decisive, while for necessity entrepreneurs, the relevant question is if formal education increases their productivity at all.

Public policy concerning entrepreneurship has implicitly distinguished between opportunity and necessity entrepreneurs in many cases. The German government, for example, offers public start-up subsidies for unemployed people, which effectively targets potential necessity entrepreneurs. ${ }^{6}$ The goal of the programme is to make participants independent of unemployment benefits. It is relevant to know if the programme allows participating nascent entrepreneurs to use their formal (and publicly subsidised) education productively. Germany is an interesting case not only because of these start-up subsidies, but also because there is concern that entrepreneurial activity in Germany is rather low in international comparison. $^{7}$

This paper also speaks to the stream of literature in labour economics that attempts to test the signalling and screening theory of education by arguing that this theory implies lower returns to education for the self-employed than for paid employees (e.g. Wolpin, 1977; Brown and Sessions, 1999; Heywood and Wei, 2004; see Chevalier et al., 2004, for a critical

\footnotetext{
${ }^{6}$ Caliendo and Künn (2011) provide an evaluation of this programme.

${ }^{7}$ Based on the Global Entrepreneurship Monitor, Kelley et al. (2011) report that the rate of early-stage entrepreneurial activity (the percentage of adults in each economy that are in the process of starting businesses or operating new businesses up to 3.5 years old) is $5.6 \%$ in Germany as compared to an average of $6.9 \%$ in the countries classified as innovation-driven economies as well. For instance, the respective rates are $5.7 \%$ in France, $7.3 \%$ in the UK and $12.3 \%$ in the US.
} 
discussion). Since the self-employed are their own bosses and no information problem occurs, they exclusively use the productivity enhancing function of education, i.e. the human capital they have built up, this literature argues. Employees, in contrast, are remunerated both for their human capital and the signalling value of education toward the employer. Employees’ additional returns to education are then attributed to the signalling value and interpreted as evidence for the signalling theory. This paper assesses to what extent the practice of pooling opportunity and necessity entrepreneurs may shed doubt on this interpretation. If necessity entrepreneurs have lower returns to education than opportunity entrepreneurs and therefore decrease the average returns for the self-employed used in these studies, the lower returns cannot be attributed to the absence of the signalling function of education toward employers, because in this respect necessity entrepreneurs do not differ from opportunity entrepreneurs.

In this study, we estimate the returns to education for opportunity and necessity entrepreneurs in comparison to paid employees using representative household panel data for Germany, the German Socio-economic Panel (SOEP). We apply a random effects IV approach to account for the endogeneity of education and consider non-random selection based on unobservables into different employment states, i.e. regular employment, opportunity entrepreneurship, necessity entrepreneurship, and non-employment. Besides socio-demographic control variables, we control for the Big Five personality traits and locus of control, which are elicited using short inventories, as well as a measure of risk aversion. These traits and preferences have been shown to be important determinants of entrepreneurial choice and success (e.g. Evans and Leighton, 1989; Cramer et al., 2002; Zhao and Seibert, 2006; Caliendo et al., 2009, 2010, 2011).

The empirical results reveal that the impact of formal education on entrepreneurial productivity differs substantially between opportunity and necessity entrepreneurs. The estimates based on the full sample indicate that the return to a year of education for opportunity entrepreneurs is 3.5 percentage points higher than the benchmark return for 
employees, which is estimated to be $8.1 \%$. The returns for necessity entrepreneurs, in sharp contrast, are 6.5 percentage points lower and not significantly different from zero. The differences between opportunity entrepreneurs and necessity entrepreneurs are significant and robust to the various specification choices tested.

The paper proceeds as follows. Section 2 develops the hypotheses to be tested from the literature. Section 3 describes the data and explains the econometric approach. Section 4 presents the results, and Section 5 concludes the analysis.

\section{Literature and hypotheses}

\subsection{Returns to education in human capital and signalling theories}

Positive returns to education may be explained by human capital theory, as pioneered by Becker (1962) and Schultz (1963), which states that education increases productivity and, therefore, wages. Alternatively, signalling theory, as largely developed by Spence (1973), argues that instead of causally increasing a person's productivity, formal education works as a signalling device to labour markets with imperfect information. According to this screening hypothesis, education helps potential employers identify suitable employees in terms of their abilities, stamina, motivation and the like. A higher educational degree signals higher inherent productivity and employers therefore offer higher wages to the more educated.

The standard method for empirically quantifying the returns to additional schooling, which also provides the basis for this analysis, is to estimate an earnings equation, as developed by Mincer (1974). This estimation consists of a regression of the natural logarithm of wages on the schooling level and other factors influencing human capital, especially work experience. According to Hartog and Oosterbeek (2007), most studies report point estimates for employees of between 5\% and 15\% higher wages for an additional year of education. The main econometric challenges in this literature are the endogeneity of education, unobserved 
heterogeneity and sample selection (e.g. Ashenfelter et al., 1999; Card, 1999; Harmon et al., 2003; Shane, 2006). Dickson and Harmon (2011) and Henderson et al. (2011) point out that researchers focus too much on a single estimated rate of return for the population and neglect how returns to education might differ between sub-populations. We argue that this critique is even more relevant for entrepreneurs because of their apparent heterogeneity and that it is crucial to distinguish between opportunity and necessity entrepreneurs.

An extensive literature attempts to assess the relative importance of the productivity enhancing (human capital) effect of education versus its information (signalling) function in explaining positive returns to education (see Riley, 2001, for a survey, and Chevalier et al., 2004, for criticism of alleged evidence for the screening hypothesis and own estimations). One strategy frequently applied to test the screening hypothesis is to compare the returns to education of employees to those of the self-employed, as discussed next.

\subsection{Returns to education of employees and entrepreneurs}

One motivation to estimate the returns to education of the self-employed has been the idea of using the self-employed as a control group to test signalling theory (e.g. Wolpin, 1977; Brown and Sessions, 1999; Heywood and Wei, 2004). ${ }^{8}$ This literature argues that the self-employed are an unscreened group, as they do not need the informative function of education for an employer. The returns to education of employees, in contrast, represent the sum of the productivity and signalling effects. The difference between a higher rate of returns for employees and a lower rate for the self-employed is then interpreted as the signalling component of the returns. One caveat of this strategy recognised by Backes-Gellner and Werner (2007) and Parker and Van Praag (2006) is that entrepreneurs may also need formal

\footnotetext{
${ }^{8}$ In this study as in many others, the self-employed are used as a measureable proxy of entrepreneurship. The concepts of self-employment and entrepreneurship are not necessarily the same, although they certainly overlap widely. Common definitions of entrepreneurship mention innovation and risk bearing, whereas the selfemployed bear income risk, but not necessarily innovate. The distinction between opportunity and necessity entrepreneurs is helpful, as opportunity entrepreneurs are closer to narrow definitions of entrepreneurship.
} 
education as a signal, e.g. for clients, employees or capital lenders. Signalling theory therefore does not provide clear predictions about the relative returns to education of entrepreneurs and employees (cf. Van Praag et al., 2009). In this study, we will show that differences in the returns to education between opportunity and necessity entrepreneurs, which cannot be due to signalling toward employers, cast further doubt on the use of the self-employed as a control group to test the signalling theory.

Other theoretical considerations predict that entrepreneurs should enjoy higher returns to education than paid employees. According to Douhan and Van Praag (2009) and Van Praag et al. (2009), entrepreneurs have more control in which ways to employ their human capital than employees, who face organisational constraints. ${ }^{9}$ Entrepreneurs have greater scope to align their business with their specific capabilities than paid employees, who have to fulfil assigned tasks, obey rules set by superiors, and stick to work descriptions that are not individually tailored to them. Entrepreneurs may therefore be in a better position to maximise the returns to their education. They also have more control over the accruals from their human capital, as they are the residual claimants of their firms and not tied to wage brackets. In this study, we render this personal control theory more precisely by noting that it should be more relevant for opportunity than for necessity entrepreneurs. The fact that necessity entrepreneurs, by definition, did not voluntarily intend to become entrepreneurs, clearly demonstrates that they do not have full control over the employment of their human capital, very much in contrast to opportunity entrepreneurs.

In their literature review of the empirical evidence, Van der Sluis et al. (2008) summarise that studies using US data tend to report returns to education that are higher for entrepreneurs than for employees, whereas in Europe the opposite is found, although studies were only available for the UK, Italy, and the Netherlands. Van Praag et al. (2009), who take into

\footnotetext{
${ }^{9}$ Benz and Frey (2008) also emphasise that entrepreneurs enjoy more autonomy and control and relate this to higher work satisfaction.
} 
account the endogeneity of education (in contrast to the studies surveyed by Van der Sluis et al., 2008), confirm higher returns for entrepreneurs in the US. Parker and Van Praag (2006) estimate entrepreneurial returns in the Netherlands that exceed estimates for paid employees reported in Levin and Plug (1999), but they do not offer an own direct comparison. ${ }^{10}$

Evidence for Germany is scarce and inconclusive. Williams (2003) reports point estimates of the returns to education for entrepreneurs between $2.5 \%$ using OLS regression up to $10.8 \%$ using an IV approach, but the effects are statistically not different from zero. Block et al. (2010) find returns of $10.5 \%$ based on a random effects IV model, without a direct comparison to paid employees. Block and Wagner (2010) focus on the characteristics and earnings differentials of opportunity and necessity entrepreneurs. Education is among various variables considered, but its endogeneity is not taken into account. The (potentially biased) estimates imply returns to education of only $4.3 \%$ for opportunity entrepreneurs and returns that are not statistically different from zero for necessity entrepreneurs. To reconcile the mixed results, this paper estimates the returns to education for opportunity and necessity entrepreneurs, directly tests for differences from the returns for employees, and accounts for the endogeneity of education and non-random self-selection.

\subsection{Necessity and opportunity entrepreneurs}

Before we derive hypotheses about the returns to education for opportunity and necessity entrepreneurs, these concepts need further clarification. The Global Entrepreneurship Monitor (GEM) distinguishes between entrepreneurs who i.) perceive a business opportunity and choose entrepreneurship as one of several career options, and ii.) who feel the necessity to engage in such activity due to the absence of other employment opportunities (Reynolds et al., 2002). In contrast to the GEM data, the data we choose for this analysis, from the German

\footnotetext{
${ }^{10}$ Co, Gang and Yun (2005) use data from Hungary and account for non-random selection; large standard errors do not allow drawing clear conclusions about differences in returns to education between entrepreneurs and employees.
} 
Socio-economic Panel, do not include information on a subjective self-classification into opportunity and necessity entrepreneurs (except in 2010, see Section 3.2), and we rely on objective information from the recent employment history to classify respondents (see Section 3.1 for our reasons for this choice of data).

We use registered unemployment before entering self-employment as a broad distinction criterion, as someone who registers as unemployed is, by definition, looking for employment. We therefore label those self-employed persons, who were registered unemployed before entering self-employment, as necessity entrepreneurs, and all others as opportunity entrepreneurs. This procedure allows us to classify all the self-employed in the sample and keep the analysis representative for the German population. By additionally controlling for individual cumulated prior unemployment experience in our regressions, we avoid that the indicator for necessity entrepreneurship picks up the potential depreciation effect of unemployment spells on human capital (Arulampalam, 2008).

To assess the sensitivity of the results with respect to the operationalisation of opportunity versus necessity entrepreneurship, we repeat the estimations using a different, more specific approach. Here we closely follow Block and Wagner (2010) and inspect the circumstances under which a self-employed person left her previous job as a paid employee. Self-employed persons who voluntarily quit their previous jobs are labelled opportunity entrepreneurs, as it is straightforward to assume that they did so in order to enter entrepreneurship. Those who lost their last jobs involuntarily because of closure of the company or dismissal are classified as necessity entrepreneurs. While this classification may be seen as more precise, a disadvantage is that by construction only those entrepreneurs can be included in the sample who had a wage job before. ${ }^{11}$ In Section 3.2, we assess the validity

\footnotetext{
${ }^{11}$ When we use this classification scheme, like Block and Wagner (2010), we only include those self-employed who lost their last wage job not more than two years before they enter self-employment; if the gap between the two employment spells is larger, one may doubt if the way the former job was ended is informative enough about the motivation to becoming an entrepreneur. Only the first self-employment spell is included in case of serial entrepreneurs, as for subsequent spells again it is harder to make a judgment on the motivation. We also
} 
of the two alternative operationalisations of opportunity and necessity entrepreneurs by exploiting direct questions for the motivations of becoming self-employed asked in 2010.

\subsection{Hypotheses for necessity and opportunity entrepreneurs}

We will derive hypotheses about the returns to education for opportunity and necessity entrepreneurs based on a novel extension of personal control theory (see Section 2.2), which originally only spoke about the difference between the total of entrepreneurs and paid employees (Douhan and Van Praag, 2009). Opportunity entrepreneurs are in the position to reap the fruits that the enhanced personal control over the employment of and the accruals from their human capital offers them as an entrepreneur. They have spotted a business opportunity that allows them the best use of their specific human capital (in the sense of Lazear, 2009; compare Becker, 1962, and Neal, 1995). Opportunity entrepreneurs can prepare for their step into entrepreneurship thoroughly beforehand - as they have alternative employment options, they can wait till the optimal time has come. If the choice to become an entrepreneur is economically rational, opportunity entrepreneurs will only make this choice if their returns exceed their opportunity costs, i.e. the wage they would earn in paid employment. ${ }^{12}$ Hence, they can use their former education investments more productively than in alternative paid employment.

In contrast, necessity entrepreneurs would not be entrepreneurs if they had alternative employment options. The fact that they are pushed into their entrepreneurial activities demonstrates that they do not have full control over the use of their human capital. Therefore, they cannot fully exploit the benefits from personal control. As entrepreneurship is their remedy of last resort, it is likely that they do not have time to develop a business idea that best fits their skills, and they cannot wait for the optimal point in time. One can argue that the ex-

exclude those self-employed from the sample whose former wage job was terminated because a limited time contract expired, because in this case classification into opportunity or necessity entrepreneurs is unclear.

${ }^{12}$ Hvide (2009) provides a model of the interaction between the decision to become an entrepreneur and the employers' efforts to keep their workers. 
ante expected payoffs from necessity entrepreneurs' investments in education do not actualise, as unexpectedly there is no demand for their formally acquired skills on the labour market; necessity entrepreneurs have to reorientate themselves. It is not wages from paid employment that constitute the opportunity costs for necessity entrepreneurs, as this alternative is not available, but rather the transfers they would receive in case of unemployment. Even if necessity entrepreneurship does not use the human capital acquired at all (which is a sunk investment in this situation), it may be more attractive than (long-term) unemployment, which also does not provide returns to human capital. In summary, we can derive three hypotheses to be tested, ceteris paribus:

Hypothesis 1: Opportunity entrepreneurs have higher returns to education than necessity entrepreneurs.

Hypothesis 2: Opportunity entrepreneurs have higher returns to education than paid employees.

Hypothesis 3: Necessity entrepreneurs have lower returns to education than paid employees.

\section{Econometric approach and data}

\subsection{Representative household panel data}

In this analysis we use the German Socio-economic Panel (SOEP), a yearly household panel survey that is representative for the population in Germany. ${ }^{13}$ In 2010 about 23,000 individuals living in more than 10,000 households were successfully interviewed. For our purpose, we prefer the SOEP to other data sources such as the Global Entrepreneurship

\footnotetext{
${ }^{13}$ The central aim of the SOEP is to collect representative micro-data about individuals and households. It is similar to the PSID (Panel Study of Income Dynamics) in the USA and the BHPS (British Household Panel Survey) in the UK. A stable set of core questions appears every year, covering population and demography; education, training, and qualification; labour market and occupational dynamics; earnings, income, and social security; housing; health; household production; and basic orientation. For a more detailed data description, see Wagner, Frick, and Schupp (2007).
} 
Monitor, because, as a general household panel, the SOEP has the advantage of offering detailed socio-economic information, in particular with respect to employment, education and income; these data have been used and tested for plausibility in labour economics and other fields extensively. Moreover, the SOEP provides a rich set of control variables unavailable in other data bases, including scores from short psychological inventories of personality traits.

We use unbalanced data consisting of the waves from 1998 to 2010, which allows us to cover several business cycles. The earnings regressions include persons who report earnings from work in employment or self-employment in their working age between 19 and 65 years of age; ${ }^{14}$ the first stage selection regressions additionally include the unemployed and those not participating in the labour market. We exclude from the sample observations of persons who are currently in education or vocational training, in military or community service, pensioners, farmers, and civil servants; as these persons are not usually confronted with the choice to become an employee or an entrepreneur while they are in these states, and their incomes are only determined by the market to a limited extent. Family members who help in a family business are also removed from the sample, since they are not entrepreneurs in the sense that they are running their own business. People are classified as entrepreneurs if they report self-employment as their primary occupational activity (see footnote 8). Education as the key variable in the Mincer type equation is measured as years of education, which assigns a standardised number of years depending on the highest degree a person attained. ${ }^{15}$

Personality characteristics are shown to influence wages (Heineck and Anger, 2010) as well as entrepreneurial entry and success (Caliendo et al., 2011); at the same time, they may also be correlated with education. Thus, it is important to control for personality traits in both the selection and earnings equations. Personality scores may serve as proxies for unobserved

\footnotetext{
${ }^{14}$ In the alternative estimation, with a more specific definition of opportunity and necessity entrepreneurs, not all the self-employed can be included in the sample (see Section 2.3).

${ }^{15}$ A university graduate, for example, is always assigned 18 years of schooling, no matter if it actually took 17 , 18 , or 19 (or more) years to graduate.
} 
ability and reduce the potential omitted variable bias in the coefficient of education (cf. Almlund et al., 2011), although we also deal with this issue using an IV approach (see below). Specifically, in 2005 and 2009, the SOEP included short inventories of the Big Five personality factors: openness, conscientiousness, extraversion, agreeableness, and neuroticism (Costa and McCrae, 1992). In 2005 and 2010, a further inventory measured locus of control (Rotter, 1966). ${ }^{16}$ Several survey waves $(2004,06,08,09,10)$ include a question about the general willingness to take risks. ${ }^{17}$ Dohmen et al. (2011) demonstrate in a field experiment with real money at stake that the answers to this survey question are good predictors for actual risk-taking behaviour.

To control for human capital acquired in addition to formal schooling and human capital depreciation, we include prior labour market and unemployment experience, measured in years, in the regressions. ${ }^{18}$ We further account for age and dummy variables indicating gender, persons with children younger than 16 years in the household, those living with a partner (married or unmarried), with a migration background, with disabilities, and those living in western Germany.

\subsection{Characteristics of opportunity and necessity entrepreneurs}

Table 1 provides descriptive statistics for paid employees and opportunity and necessity entrepreneurs based on the full estimation sample (variable descriptions appear in Table A 1 in the Appendix). Opportunity entrepreneurs exhibit the highest and necessity entrepreneurs the lowest mean hourly gross earnings; the $t$-tests to the right reveal that these differences are

\footnotetext{
${ }^{16}$ In the inventories, the respondents were asked how much they agreed with different statements about themselves (on 7-point Likert scales). Fifteen items assessed the Big Five personality traits (3 items for each trait), plus internal and external locus of control were measured by 10 items.

${ }^{17}$ In survey waves where no information is available, we impute scores of the same respondents from the past, where possible, or otherwise from later interviews. This assumes that personality traits are stable for adults at least for some years, which is supported by the evidence (Cobb-Clark and Schurer, 2011, 2012).

${ }^{18}$ Prior experience excludes the current year to avoid endogeneity. A squared term of work experience is also included.
} 
statistically significant. ${ }^{19}$ The variance of hourly earnings is greater for both groups of entrepreneurs than for employees, which reflects the greater risks associated with entrepreneurship. Necessity entrepreneurs, on average, have fewer years of education than opportunity entrepreneurs, but still more education than employees. This is consistent with the observation of Wagner (2005) and indicates that those unemployed who become entrepreneurs differ from the average unemployed, who have lower education than employees (cf. Hinz and Jungbauer-Gans, 1999). The share of women among the self-employed is only about 35\% and does not differ significantly between opportunity and necessity entrepreneurs. Necessity entrepreneurs are more concentrated in eastern Germany, in comparison to opportunity entrepreneurs, because of the higher unemployment rate. ${ }^{20}$ Opportunity entrepreneurs more often had a self-employed father when they were 15 years old, and they have the most educated fathers. Among opportunity (necessity) entrepreneurs, 51\% (24\%) have at least one employee, and 36\% (23\%) are liberal professionals like self-employed physicians, lawyers, architects, journalists, and artists. ${ }^{21}$ Both types of entrepreneurs work about the same number of hours per week and significantly more than paid employees. ${ }^{22}$

Concerning the personality traits, opportunity and necessity entrepreneurs do not differ very much from one another; in comparison to employees, both exhibit the pattern described in Caliendo et al. (2011) with higher scores in openness to experience, extraversion, a more internal locus of control (this means they believe that their own actions determine their outcomes rather than luck or fate), and they are more willing to take risks.

\footnotetext{
${ }^{19}$ Parker (1997) demonstrates that income inequality among the self-employed in the UK rose between 1976 and 1991 because of increasing heterogeneity of the self-employed, which is consistent with a more important role of necessity entrepreneurs.

${ }^{20}$ This picture does not change when persons who were already self-employed in 1998 are excluded from the sample, which results in comparing only persons who became self-employed nine or more years after reunification in 1990.

${ }^{21}$ Some of the characteristics described here, such as the employment of workers, are not used as control variables in the regressions because they are presumably endogeneous; see Section 3.1 for the list of controls.

${ }^{22}$ Parker et al. (2005) note that the longer hours worked by self-employed persons may partly be explained by self-insurance against their higher income risk.
} 
Table 1: Descriptive statistics (full sample)

\begin{tabular}{|c|c|c|c|c|c|c|c|c|c|}
\hline & \multirow{2}{*}{\multicolumn{2}{|c|}{ Paid employees (E) }} & \multirow{2}{*}{\multicolumn{2}{|c|}{$\begin{array}{l}\text { Opportunity } \\
\text { entrepreneurs (OE) }\end{array}$}} & \multirow{2}{*}{\multicolumn{2}{|c|}{$\begin{array}{l}\text { Necessity } \\
\text { entrepreneurs (NE) }\end{array}$}} & \multicolumn{3}{|c|}{$t$-tests of equal means } \\
\hline & & & & & & & OE vs E & NE vs E & OE vs NE \\
\hline & Mean & Std dev. & Mean & Std dev. & Mean & Std dev. & $p$-value & $p$-value & $p$-value \\
\hline grossEarnings & 14.18 & 8.69 & 21.38 & 23.92 & 12.55 & 15.90 & 0.00 & 0.00 & 0.00 \\
\hline educ & 12.50 & 2.55 & 13.87 & 2.93 & 13.37 & 2.81 & 0.00 & 0.00 & 0.00 \\
\hline workExp & 17.10 & 10.65 & 19.97 & 10.25 & 17.01 & 9.18 & 0.00 & 0.75 & 0.00 \\
\hline unemplExp & 0.27 & 1.09 & 0.10 & 0.55 & 0.94 & 1.89 & 0.00 & 0.00 & 0.00 \\
\hline age & 41.58 & 10.56 & 45.55 & 9.87 & 43.10 & 9.10 & 0.00 & 0.00 & 0.00 \\
\hline female & 0.49 & 0.50 & 0.35 & 0.48 & 0.36 & 0.48 & 0.00 & 0.00 & 0.50 \\
\hline west & 0.74 & 0.44 & 0.80 & 0.40 & 0.51 & 0.50 & 0.00 & 0.00 & 0.00 \\
\hline partner & 0.77 & 0.42 & 0.81 & 0.39 & 0.77 & 0.42 & 0.00 & 0.49 & 0.02 \\
\hline children & 0.38 & 0.49 & 0.40 & 0.49 & 0.41 & 0.49 & 0.00 & 0.14 & 0.96 \\
\hline handicapped & 0.06 & 0.23 & 0.04 & 0.19 & 0.04 & 0.21 & 0.00 & 0.06 & 0.45 \\
\hline migrant & 0.13 & 0.33 & 0.08 & 0.28 & 0.10 & 0.30 & 0.00 & 0.00 & 0.16 \\
\hline openness & 4.49 & 1.15 & 4.91 & 1.11 & 4.97 & 1.08 & 0.00 & 0.00 & 0.13 \\
\hline conscientiousness & 5.99 & 0.85 & 5.98 & 0.92 & 5.97 & 0.89 & 0.18 & 0.44 & 0.85 \\
\hline extraversion & 4.85 & 1.11 & 5.06 & 1.11 & 5.14 & 1.07 & 0.00 & 0.00 & 0.02 \\
\hline agreeableness & 5.40 & 0.95 & 5.36 & 0.96 & 5.38 & 0.99 & 0.00 & 0.70 & 0.43 \\
\hline neuroticism & 3.85 & 1.19 & 3.65 & 1.21 & 3.79 & 1.13 & 0.00 & 0.09 & 0.00 \\
\hline internal locus & 5.75 & 0.93 & 5.93 & 0.87 & 5.90 & 0.91 & 0.00 & 0.00 & 0.39 \\
\hline external locus & 3.62 & 0.91 & 3.33 & 0.91 & 3.58 & 0.99 & 0.00 & 0.21 & 0.00 \\
\hline risk tolerance & 4.68 & 2.15 & 5.54 & 2.18 & 5.68 & 2.03 & 0.00 & 0.00 & 0.05 \\
\hline father selfempl & 0.07 & 0.26 & 0.17 & 0.38 & 0.10 & 0.30 & 0.00 & 0.00 & 0.00 \\
\hline father's educ & 11.30 & 2.34 & 12.31 & 2.96 & 12.07 & 2.91 & 0.00 & 0.00 & 0.01 \\
\hline mother's educ & 10.52 & 1.93 & 11.16 & 2.50 & 11.19 & 2.35 & 0.00 & 0.00 & 0.73 \\
\hline childrenBelow6 & 0.19 & 0.48 & 0.21 & 0.51 & 0.21 & 0.49 & 0.00 & 0.18 & 0.99 \\
\hline occTrainedFor & 0.62 & 0.48 & 0.66 & 0.47 & 0.57 & 0.50 & 0.00 & 0.01 & 0.00 \\
\hline employsWorkers & & & 0.51 & 0.50 & 0.24 & 0.42 & 0.00 & 0.00 & 0.00 \\
\hline libProfessional & & & 0.36 & 0.48 & 0.23 & 0.42 & 0.00 & 0.00 & 0.00 \\
\hline hoursWorked & 37.85 & 12.34 & 44.45 & 17.48 & 44.36 & 16.98 & 0.00 & 0.00 & 0.89 \\
\hline Person-year obs. & 71446 & & 5950 & & 975 & & & & \\
\hline
\end{tabular}

Notes: The three rightmost columns report $p$-values of two-sample $t$-tests with unequal variances. Definitions of the variables appear in Table A 1.

Source: Authors’ calculations based on SOEPv27, 1998-2010.

Importantly, $66 \%$ of opportunity entrepreneurs report that they are working in the profession that they were trained for, but only $62 \%$ of the paid employees and only $57 \%$ of the necessity entrepreneurs make this claim; all these differences are significant. ${ }^{23}$ This finding supports the personal control theory extended in this paper (Section 2.4): Opportunity entrepreneurs can make better use of their specific human capital than paid employees, whereas some of the specific human capital of necessity entrepreneurs lies idle. Figure 2 demonstrates that this gap between opportunity and necessity entrepreneurs with respect to

${ }^{23}$ The wording of the SOEP question is: "Is [your] position the same as the profession for which you were educated or trained?" with the response options "Yes"; "No"; "In training”; and "Has no job training". We construct a dummy variable with 1 referring to "Yes" and 0 to "No" or "In training"; respondents without job training are excluded. 
the share working in the profession trained for opens up at almost all levels of education. ${ }^{24}$ Table A 2 in the Appendix shows descriptive statistics for the alternative operationalisation of opportunity and necessity entrepreneurs (see Section 2.3), which provides a similar picture. ${ }^{25}$

Figure 2: Share of entrepreneurs working in the profession trained for

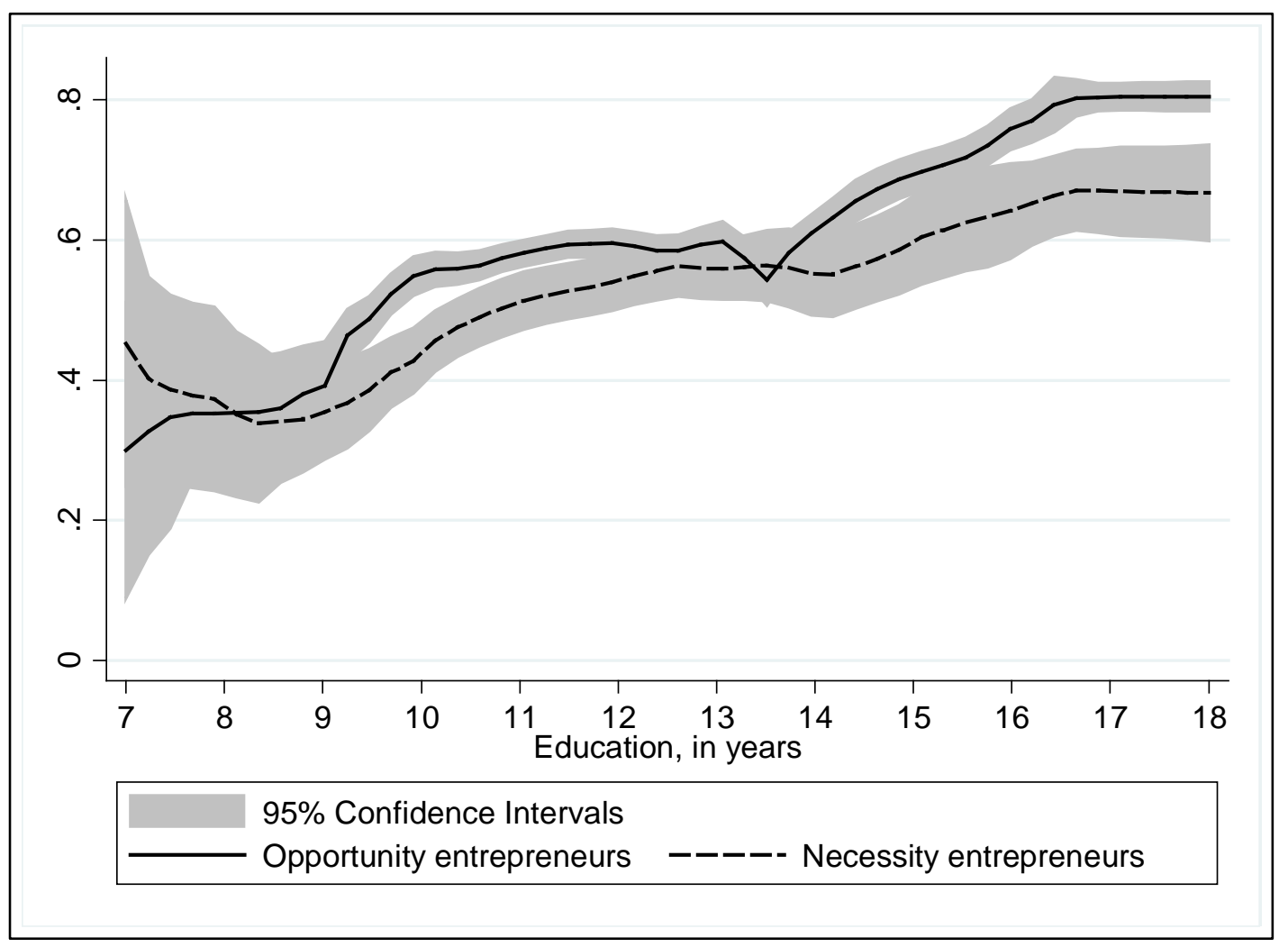

Note: The figure shows bivariate local mean regressions of the dummy variable indicating if an entrepreneur works in the profession she was trained for on the years of education, separately for opportunity and necessity entrepreneurs.

Source: Authors’ calculations based on SOEPv27, 1998-2010.

To further assess if our classifications capture the intended concepts of necessity and opportunity entrepreneurs, we evaluate novel special questions that are exclusively available in the 2010 SOEP questionnaire. These questions were posed to respondents who indicated

\footnotetext{
${ }^{24}$ The difference between the two groups is always positive when it is significant; the insignificant cases where the gap is negative can easily be explained by sampling error.

${ }^{25}$ Using our baseline method of exploiting prior unemployment, we classify $14 \%$ of the self-employed as necessity entrepreneurs (Table 1), which is less than the share reported for Germany by the Global Entrepreneurship Monitor (Figure 1) based on self-classification. Obviously, our group of opportunity entrepreneurs includes some people that the GEM would classify as necessity entrepreneurs. Our second approach of inspecting the way an entrepreneur's prior job was terminated is more specific with regard to opportunity entrepreneurs, but not all the self-employed can be classified using this approach. Here, even 36\% of the self-employed that can be classified are labelled as necessity entrepreneurs (Table A 2 in the Appendix), which exceed the share in the GEM. Thus, our two classification approaches provide upper and lower bounds.
} 
that they had entered self-employment in the previous year and sought the reasons for their new self-employment. Table 2 shows the descriptive results. The columns labelled "general definition" refer to the baseline classification based on prior unemployment, and "specific definition” refers to the alternative classification based on the way the last job was terminated. For opportunity entrepreneurs, the wish to be their own boss is more important than for necessity entrepreneurs, while for necessity entrepreneurs, escaping unemployment and being unable to find employment are more important reasons for becoming self-employed. These differences are statistically significant when the general definition is used, as indicated by $t$ tests; for the specific definition, the differences are all insignificant, presumably because of the smaller sample size, but the point estimates tell the same story. ${ }^{26}$ We conclude that our operationalisations capture the concepts of opportunity and necessity entrepreneurs well. ${ }^{27}$

Table 2: Reasons for becoming an entrepreneur

\begin{tabular}{|c|c|c|c|c|c|c|}
\hline & \multicolumn{2}{|c|}{ General definition } & \multicolumn{4}{|c|}{ Specific definition } \\
\hline & $\begin{array}{l}\text { Oppor. } \\
\text { entre. } \\
\text { mean }\end{array}$ & $\begin{array}{l}\text { Necess. } \\
\text { entre. }\end{array}$ & $\begin{array}{l}\text { OE vs } \\
\mathrm{NE} \\
p \text {-value }\end{array}$ & $\begin{array}{l}\text { Oppor. } \\
\text { entre. } \\
\text { Mean }\end{array}$ & $\begin{array}{l}\text { Necess. } \\
\text { entre. }\end{array}$ & $\begin{array}{l}\mathrm{OE} \text { vs } \\
\mathrm{NE} \\
p \text {-value }\end{array}$ \\
\hline \multicolumn{7}{|c|}{ Reasons for having entered self-employment on a scale from 1 (does not apply at all) to 7 (fully applies) } \\
\hline I have always wanted to be my own boss. & 5.12 & 3.94 & 0.09 & 5.50 & 4.77 & 0.40 \\
\hline I did not want to be unemployed anymore. & 2.24 & 5.33 & 0.00 & 2.60 & 3.31 & 0.55 \\
\hline Others advised me to start up a business. & 3.00 & 2.35 & 0.30 & 3.10 & 2.62 & 0.63 \\
\hline I discovered a market gap. & 2.52 & 2.72 & 0.74 & 2.70 & 2.85 & 0.87 \\
\hline I wanted to earn more money. & 4.06 & 3.61 & 0.56 & 5.00 & 4.46 & 0.64 \\
\hline I did not find employment (anymore). & 1.88 & 3.56 & 0.02 & 1.70 & 2.23 & 0.46 \\
\hline I had an idea that I really wanted to implement. & 3.33 & 3.28 & 0.94 & 3.30 & 3.23 & 0.95 \\
\hline $\begin{array}{l}\text { I was disadvantaged at my previous workplace. } \\
\text { Additional questions: } 1 \text { (yes) or } 0 \text { (no) }\end{array}$ & 2.63 & 2.50 & 0.85 & 3.10 & 2.23 & 0.39 \\
\hline I actively searched before starting this job. & 0.30 & 0.37 & 0.63 & 0.25 & 0.29 & 0.85 \\
\hline I received start-up subsidies. & 0.27 & 0.68 & 0.00 & 0.36 & 0.54 & 0.41 \\
\hline Person-year obs. & 486 & 99 & & 103 & 74 & \\
\hline
\end{tabular}

Notes: The SOEP questionnaire 2010 included some special questions that were directed at respondents who indicated that they became self-employed in the previous year. The general definition refers to the classification based on prior unemployment; the specific definition refers to the classification based on the way the last job was terminated. The columns headed “OE vs NE" include $p$-values of two-sample $t$-tests of equal means comparing opportunity and necessity entrepreneurs (with unequal variances).

Source: Authors’ calculations based on SOEPv27, 2010.

\footnotetext{
${ }^{26}$ Necessity entrepreneurs are also more likely to receive start-up subsidies (note that these are not included in the gross earnings reported and therefore not used in the regressions), which is very plausible because most subsidies are only available for the unemployed.

${ }^{27}$ We cannot make use of these special questions to classify opportunity and necessity entrepreneurs in our regressions because the sample size would be too small if we used the year 2010 only.
} 


\subsection{Earnings equation and ability bias}

The basis for estimating the returns to education of paid employees, opportunity and necessity entrepreneurs is a Mincerian earnings function for person $i$ in year $t$. Consider

$$
\begin{aligned}
\ln \left(w_{i t}\right)= & \beta_{0}+\beta_{1} \text { educ }_{i t}+\beta_{2} \text { educ }_{i t} * \text { oppEntre }_{i t}+\beta_{3} \text { educ }_{i t} * \text { necEntre }_{i t}+ \\
& \beta_{4} \text { oppEntre }_{i t}+\beta_{5} \text { necEntre }_{i t}+\beta_{c}^{\prime} X_{i t}+\beta_{\lambda} \lambda_{i t}+\theta_{t} d_{t}+\mu_{i}+\varepsilon_{i t}
\end{aligned}
$$

where ln denotes the natural logarithm, $w_{i t}$ gross hourly earnings, educ $i t$ years of education, educ $_{i t}{ }^{*} x$ its interactions with $x$, oppEntre it $_{\text {and }}$ necEntre $e_{i t}$ dummy variables marking opportunity and necessity entrepreneurs, $X_{i t}$ a vector of control variables (see Section 3.1), $\lambda_{\text {it }}$ a selection correction term (see Section 3.4), $d_{t}$ year dummies, $\beta$ and $\theta$ coefficients to be estimated, $\mu_{i}$ a time invariant random error component and $\varepsilon_{i t}$ a time varying error component (random effects model). The coefficient $\beta_{1}$ measures the returns to education for employees (the reference group), the sum of $\beta_{1}+\beta_{2}$ the returns for opportunity and $\beta_{1}+\beta_{3}$ for necessity entrepreneurs. To facilitate comparisons with the extant literature, we additionally estimate eq. (1) including a general self-employment dummy and its interaction with education instead of distinguishing between opportunity and necessity entrepreneurs.

For a consistent estimation of this equation, endogeneity of education and its interactions with oppEntre and necEntre must be taken into account, as unobserved ability may induce people to acquire more education and at the same time have a direct effect on earnings, as discussed extensively in the literature (e.g. Ashenfelter et al., 1999; Harmon et al., 2003). Some candidate instrumental variables (IV) used in the literature, which for example exploit compulsory schooling laws (Angrist and Kruger, 1991), are criticised because these instruments tend to be weak (Bound et al., 1995) or to identify a local treatment effect for a sub-group that is not representative (Card, 1999). Family background variables do not suffer from these problems, as they have strong predictive power for education that is not limited to a specific subgroup. A possible concern with these variables is that the family background may have a direct effect on earnings that does not work through education. Specifically 
considering father's education, Hoogerheide et al. (2012) investigate this potential issue using Bayesian analysis, based on the SOEP, the same data we employ. By experimenting with relaxations of the strict exclusion restriction, they show that the size of a bias introduced by a potential direct effect of father's education on wages is typically smaller than the width of the 95\% posterior interval of the education coefficient of interest in the IV model, even if the strict exogeneity assumption were substantially violated. They conclude that using father’s education as an instrument in earnings regressions is a viable option, especially considering the problems with alternatives mentioned above. Therefore, we use father's education and its interactions with oppEntre and necEntre as excluded instruments to account for the endogeneity of education and its interactions. ${ }^{28}$ Specifically, we employ the efficient G2SLS random effects IV estimator (Balestra and Varadharajan-Krishnakumar, 1987).

\subsection{Non-random selection}

Apart from the endogeneity of education, two potential mechanisms of non-random selfselection may be at play. First, persons who are unemployed or who do not participate on the labour market do not report a wage and must be excluded from the earnings equation. We address this with a Heckman (1979) style two-step selection correction, which in the first step estimates binary participation equations separately for each year and in the second step introduces the combined predicted inverse Mills ratio $\lambda$ as an additional regressor when estimating equation (1) by G2SLS. ${ }^{29}$

\footnotetext{
${ }^{28}$ Father's number of years in education is calculated based on his educational degree, analogously to the calculation of the respondent's own education. We do not use mother's education or other family background variables, as these variables have not been investigated as potential instruments in the way described, and as information on mother's education is often missing in the data.

${ }^{29}$ For better identification, three variables are included in the selection equation, but not in eq. (1). The first two are the number of children in the household below the age of 6 , which is the usual school entrance year in Germany, and its interaction with the female dummy, as these variables are strong predictors for parents' work participation; in eq. (1), we control for the presence of children below 17. The third exclusion restriction is a dummy variable indicating whether the father was self-employed when the respondent was 15 years old, as this helps to predict participation, especially as an entrepreneur (cf. Taylor, 1996). Taylor (2001) reports that a selfemployed father increases the probability of becoming self-employed, but does not influence performance (see also Fairlie and Robb, 2007). We confirm that the three variables are jointly highly significant in the selection
} 
Second, the non-random selection into self-employment, and more specifically, into opportunity and necessity entrepreneurs may potentially introduce bias. ${ }^{30}$ To assess if this is practically relevant in this application, we additionally estimate equations of the following type separately for the three employment states $j \in\{$ paid employee; necessity entrepreneur; opportunity entrepreneur \}, controlling for non-random selection into each of these states:

$$
\ln \left(w_{i t}\right)=\beta_{0 j}+\beta_{1 j} e d u c_{i t}+\beta_{c j}^{\prime} X_{i t}+\beta_{\lambda j} \lambda_{i t j}+\theta_{t j} d_{t}+\mu_{i}+\varepsilon_{i t} .
$$

Education again is treated as endogenous, and we estimate G2SLS models as above. The first step selection equation now becomes a multinomial logit model that is used to estimate probabilities of belonging to one of the four groups $j \in\{$ not working; paid employee; necessity entrepreneur; opportunity entrepreneur\}, with $j=$ not working as the omitted category:

$$
\mathrm{P}\left(J_{i t}=j \mid X_{i t}^{S}\right)=\mathrm{G}\left(\gamma_{t j}^{\prime} X_{i t}^{S}\right)=\frac{\exp \left(\gamma_{t j}^{\prime} X_{i t}^{S}\right)}{1+\sum_{k=2}^{4} \exp \left(\gamma_{t k}^{\prime} X_{i t}^{S}\right)}
$$

where the set of explanatory variables $X_{i t}^{S}$ includes $X_{i t}$ from above and the additional variables described in footnote 29. Again the multinomial logit models are estimated separately for each year, which allows calculating selection correction terms (Lee, 1983),

$$
\lambda_{i t j}=\frac{\phi\left(\Phi^{-1}\left(\mathrm{G}\left(\gamma_{t j}^{\prime} X_{i t}\right)\right)\right.}{\mathrm{G}\left(\gamma_{t j}^{\prime} X_{i t}\right)},
$$

which are then combined over years and used as an additional regressor in eq. (2). ${ }^{31}$

equations. Furthermore, in the specifications that treat education as endogenous, we use father's education in the selection equations instead of education; see Wooldridge (2002) for the econometric combination of selection correction and IV methods.

${ }^{30}$ Interestingly, Taylor (1999) reports that formal qualifications are no important determinants of the exit rate from entrepreneurship.

${ }^{31}$ Although the coefficients of the first stage selection equation are not of specific interest, we conduct 39 Hausman (1978) tests (13 years times 3 categories) to test the independence of irrelevant alternatives assumption underlying the multinomial logit model. The null hypothesis is rejected thrice at a $10 \%$ significance level, which is within expectations given the probability of a false rejection. In 15 cases, negative $\chi^{2}$ test statistics occur; this does not mean a rejection of the null, but may indicate that the asymptotic assumptions of the Hausman test are not met in these instances. 


\section{Empirical results}

\subsection{Results for the full representative sample}

In this section, we first examine the results when classification into opportunity and necessity entrepreneurs is based on prior unemployment (general definition), using the full representative sample; in the next section, we will consider the alternative, more specific classification, which considers the way the last job was terminated, using a sub-sample where these information are observed (see Section 2.3). Referring to the first classification approach, the first column of Table 3 shows the results from estimating the baseline earnings equation (1) employing the G2SLS random effects IV estimator. The point estimate for the return to education of employees, the reference group, is $8.1 \%$ for a year of education, which is in the expected range. The return of opportunity entrepreneurs is 3.5 percentage points higher (43\% in relative terms) and the return of necessity entrepreneurs as much as 6.5 percentage points (80\%) lower. The three coefficients are significantly different from zero at the $1 \%$ level, and the returns of opportunity entrepreneurs are significantly higher than those of necessity entrepreneurs ( $p$-value below 0.001). The data thus support all three hypotheses developed in

Section 2.4. Furthermore, the returns to education of necessity entrepreneurs are not significantly different from zero $(p$-value $=0.308)$, indicating that necessity entrepreneurs are unable to use their formal education productively.

The estimation shown in the second column does not distinguish between opportunity and necessity entrepreneurs, as in the prior literature. The returns to education of the selfemployed are on average 1.9 percentage points higher than those of employees (significant at the 5\% level). This approach hides the statistically and economically important heterogeneity between the two types of entrepreneurs revealed in column 1. 
Table 3: Joint earnings regressions with general definition of entrepreneurial types

\begin{tabular}{|c|c|c|c|c|c|c|}
\hline & $\begin{array}{l}\text { RE G2SLS } \\
\text { Full sample }\end{array}$ & $\begin{array}{l}\text { RE G2SLS } \\
\text { Full sample }\end{array}$ & $\begin{array}{l}\text { RE G2SLS } \\
\text { No liberal } \\
\text { professionals }\end{array}$ & $\begin{array}{l}\text { RE G2SLS } \\
\text { No liberal } \\
\text { professionals }\end{array}$ & $\begin{array}{l}\text { RE } \\
\text { Full sample }\end{array}$ & $\begin{array}{l}\text { RE } \\
\text { Full sample }\end{array}$ \\
\hline educ & $\begin{array}{l}0.0812^{* * *} \\
(0.0048)\end{array}$ & $\begin{array}{l}0.0825 * * * \\
(0.0048)\end{array}$ & $\begin{array}{l}0.0804 * * * \\
(0.0046)\end{array}$ & $\begin{array}{l}0.0806^{* * *} \\
(0.0048)\end{array}$ & $\begin{array}{l}0.0694 * * * \\
(0.0022)\end{array}$ & $\begin{array}{l}0.0698 * * * \\
(0.0022)\end{array}$ \\
\hline educ x oppEntre & $\begin{array}{l}0.0349 * * * \\
(0.0081)\end{array}$ & & $\begin{array}{l}0.0302^{* *} \\
(0.0120)\end{array}$ & & $\begin{array}{l}0.0042 \\
(0.0069)\end{array}$ & \\
\hline educ $\mathrm{x}$ necEntre & $\begin{array}{l}-0.0648 * * * \\
(0.0157)\end{array}$ & & $\begin{array}{l}-0.0664^{* * *} \\
(0.0235)\end{array}$ & & $\begin{array}{l}-0.0373 * * \\
(0.0154)\end{array}$ & \\
\hline oppEntre & $\begin{array}{l}-0.5587 * * * \\
(0.1102)\end{array}$ & & $\begin{array}{l}-0.4964^{* * *} \\
(0.1535)\end{array}$ & & $\begin{array}{l}-0.1326 \\
(0.1004)\end{array}$ & \\
\hline necEntre & $\begin{array}{l}0.6500 * * * \\
(0.2104)\end{array}$ & & $\begin{array}{l}0.6367^{* *} \\
(0.3000)\end{array}$ & & $\begin{array}{l}0.2978 \\
(0.2124)\end{array}$ & \\
\hline educ $x$ selfempl & & $\begin{array}{l}0.0186^{* *} \\
(0.0075)\end{array}$ & & $\begin{array}{l}0.0127 \\
(0.0112)\end{array}$ & & $\begin{array}{l}-0.0023 \\
(0.0067)\end{array}$ \\
\hline selfempl & & $\begin{array}{l}-0.3597 * * * \\
(0.1015)\end{array}$ & & $\begin{array}{l}-0.2896 * * \\
(0.1430)\end{array}$ & & $\begin{array}{l}-0.0689 \\
(0.0957)\end{array}$ \\
\hline workExp & $\begin{array}{l}0.0425 * * * \\
(0.0015)\end{array}$ & $\begin{array}{l}0.0425 * * * \\
(0.0015)\end{array}$ & $\begin{array}{l}0.0421 * * * \\
(0.0015)\end{array}$ & $\begin{array}{l}0.0419 * * * \\
(0.0015)\end{array}$ & $\begin{array}{l}0.0393 * * * \\
(0.0019)\end{array}$ & $\begin{array}{l}0.0394 * * * \\
(0.0019)\end{array}$ \\
\hline workExp squared & $\begin{array}{l}-0.0059 * * * \\
(0.0002)\end{array}$ & $\begin{array}{l}-0.0059 * * * \\
(0.0002)\end{array}$ & $\begin{array}{l}-0.0058^{* * *} \\
(0.0002)\end{array}$ & $\begin{array}{l}-0.0058^{* * *} \\
(0.0002)\end{array}$ & $\begin{array}{l}-0.0058^{* * *} \\
(0.0003)\end{array}$ & $\begin{array}{l}-0.0058^{* * *} \\
(0.0003)\end{array}$ \\
\hline unemplExp & $\begin{array}{l}-0.0733^{* * *} \\
(0.0030)\end{array}$ & $\begin{array}{l}-0.0733^{* * *} \\
(0.0030)\end{array}$ & $\begin{array}{l}-0.0712^{* * *} \\
(0.0029)\end{array}$ & $\begin{array}{l}-0.0723^{* * *} \\
(0.0029)\end{array}$ & $\begin{array}{l}-0.0793^{* * *} \\
(0.0053)\end{array}$ & $\begin{array}{l}-0.0799 * * * \\
(0.0053)\end{array}$ \\
\hline age & $\begin{array}{l}-0.0077 * * * \\
(0.0011)\end{array}$ & $\begin{array}{l}-0.0078^{* * *} \\
(0.0011)\end{array}$ & $\begin{array}{l}-0.0077 * * * \\
(0.0011)\end{array}$ & $\begin{array}{l}-0.0076^{* * *} \\
(0.0011)\end{array}$ & $\begin{array}{l}-0.0055^{* * *} \\
(0.0013)\end{array}$ & $\begin{array}{l}-0.0055^{* * *} \\
(0.0013)\end{array}$ \\
\hline female & $\begin{array}{l}-0.2043^{* * *} \\
(0.0084)\end{array}$ & $\begin{array}{l}-0.2047^{* * *} \\
(0.0084)\end{array}$ & $\begin{array}{l}-0.2036^{* * *} \\
(0.0078)\end{array}$ & $\begin{array}{l}-0.2041^{* * *} \\
(0.0082)\end{array}$ & $\begin{array}{l}-0.2056^{* * *} \\
(0.0090)\end{array}$ & $\begin{array}{l}-0.2060^{* * *} \\
(0.0090)\end{array}$ \\
\hline west & $\begin{array}{l}0.3111^{* * *} \\
(0.0088)\end{array}$ & $\begin{array}{l}0.3123 * * * \\
(0.0088)\end{array}$ & $\begin{array}{l}0.3143^{* * *} \\
(0.0083)\end{array}$ & $\begin{array}{l}0.3102^{* * *} \\
(0.0086)\end{array}$ & $\begin{array}{l}0.2903^{* * *} \\
(0.0129)\end{array}$ & $\begin{array}{l}0.2917^{* * * *} \\
(0.0130)\end{array}$ \\
\hline partner & $\begin{array}{l}0.0289 * * * \\
(0.0054)\end{array}$ & $\begin{array}{l}0.0292 * * * \\
(0.0054)\end{array}$ & $\begin{array}{l}0.0314 * * * \\
(0.0053)\end{array}$ & $\begin{array}{l}0.0306 * * * \\
(0.0053)\end{array}$ & $\begin{array}{l}0.0267 * * * \\
(0.0071)\end{array}$ & $\begin{array}{l}0.0269 * * * \\
(0.0071)\end{array}$ \\
\hline children & $\begin{array}{l}0.0113 * * \\
(0.0044)\end{array}$ & $\begin{array}{l}0.0107 * * \\
(0.0044)\end{array}$ & $\begin{array}{l}0.0102^{* *} \\
(0.0044)\end{array}$ & $\begin{array}{l}0.0094 * * \\
(0.0044)\end{array}$ & $\begin{array}{l}0.0103^{*} \\
(0.0057)\end{array}$ & $\begin{array}{l}0.0101 * \\
(0.0057)\end{array}$ \\
\hline handicapped & $\begin{array}{l}-0.0391^{* * *} \\
(0.0093)\end{array}$ & $\begin{array}{l}-0.0385^{* * *} \\
(0.0093)\end{array}$ & $\begin{array}{l}-0.0432^{* * *} \\
(0.0091)\end{array}$ & $\begin{array}{l}-0.0407^{* * * *} \\
(0.0091)\end{array}$ & $\begin{array}{l}-0.0364 * * * \\
(0.0124)\end{array}$ & $\begin{array}{l}-0.0364 * * * \\
(0.0124)\end{array}$ \\
\hline migrant & $\begin{array}{l}0.0168 \\
(0.0119)\end{array}$ & $\begin{array}{l}0.0176 \\
(0.0120)\end{array}$ & $\begin{array}{l}0.0159 \\
(0.0110)\end{array}$ & $\begin{array}{l}0.0169 \\
(0.0116)\end{array}$ & $\begin{array}{l}0.0126 \\
(0.0125)\end{array}$ & $\begin{array}{l}0.0127 \\
(0.0126)\end{array}$ \\
\hline openness & $\begin{array}{l}0.0001 \\
(0.0033)\end{array}$ & $\begin{array}{l}0.0002 \\
(0.0033)\end{array}$ & $\begin{array}{l}0.0023 \\
(0.0032)\end{array}$ & $\begin{array}{l}0.0022 \\
(0.0032)\end{array}$ & $\begin{array}{l}0.0015 \\
(0.0034)\end{array}$ & $\begin{array}{l}0.0016 \\
(0.0035)\end{array}$ \\
\hline conscientiousness & $\begin{array}{l}0.0007 \\
(0.0031)\end{array}$ & $\begin{array}{l}0.0005 \\
(0.0031)\end{array}$ & $\begin{array}{l}-0.0003 \\
(0.0030)\end{array}$ & $\begin{array}{l}-0.0004 \\
(0.0030)\end{array}$ & $\begin{array}{l}0.0013 \\
(0.0035)\end{array}$ & $\begin{array}{l}0.0012 \\
(0.0036)\end{array}$ \\
\hline extraversion & $\begin{array}{l}-0.0046 \\
(0.0032)\end{array}$ & $\begin{array}{l}-0.0046 \\
(0.0032)\end{array}$ & $\begin{array}{l}-0.0051 \\
(0.0031)\end{array}$ & $\begin{array}{l}-0.0050 \\
(0.0032)\end{array}$ & $\begin{array}{l}-0.0043 \\
(0.0036)\end{array}$ & $\begin{array}{l}-0.0043 \\
(0.0036)\end{array}$ \\
\hline agreeableness & $\begin{array}{l}-0.0101^{* * *} \\
(0.0030)\end{array}$ & $\begin{array}{l}-0.0101^{* * *} \\
(0.0030)\end{array}$ & $\begin{array}{l}-0.0098 * * * \\
(0.0029)\end{array}$ & $\begin{array}{l}-0.0091^{* * *} \\
(0.0029)\end{array}$ & $\begin{array}{l}-0.0079 * * \\
(0.0035)\end{array}$ & $\begin{array}{l}-0.0080^{* *} \\
(0.0035)\end{array}$ \\
\hline neuroticism & $\begin{array}{l}-0.0159 * * * \\
(0.0030)\end{array}$ & $\begin{array}{l}-0.0163^{* * *} \\
(0.0030)\end{array}$ & $\begin{array}{l}-0.0165^{* * *} \\
(0.0029)\end{array}$ & $\begin{array}{l}-0.0165^{* * *} \\
(0.0030)\end{array}$ & $\begin{array}{l}-0.0138^{* * *} \\
(0.0035)\end{array}$ & $\begin{array}{l}-0.0140^{* * *} \\
(0.0035)\end{array}$ \\
\hline internal locus & $\begin{array}{l}0.0067 * * \\
(0.0032)\end{array}$ & $\begin{array}{l}0.0068 * * \\
(0.0032)\end{array}$ & $\begin{array}{l}0.0048 \\
(0.0031)\end{array}$ & $\begin{array}{l}0.0051 \\
(0.0031)\end{array}$ & $\begin{array}{l}0.0043 \\
(0.0033)\end{array}$ & $\begin{array}{l}0.0045 \\
(0.0033)\end{array}$ \\
\hline external locus & $\begin{array}{l}-0.0392^{* * *} \\
(0.0037)\end{array}$ & $\begin{array}{l}-0.0389 * * * \\
(0.0037)\end{array}$ & $\begin{array}{l}-0.0421^{* * *} \\
(0.0035)\end{array}$ & $\begin{array}{l}-0.0405^{* * *} \\
(0.0036)\end{array}$ & $\begin{array}{l}-0.0381^{* * *} \\
(0.0037)\end{array}$ & $\begin{array}{l}-0.0382^{* * *} \\
(0.0037)\end{array}$ \\
\hline risk tolerance & $\begin{array}{l}0.0014 \\
(0.0021)\end{array}$ & $\begin{array}{l}0.0011 \\
(0.0021)\end{array}$ & $\begin{array}{l}0.0019 \\
(0.0021)\end{array}$ & $\begin{array}{l}0.0014 \\
(0.0021)\end{array}$ & $\begin{array}{l}0.0013 \\
(0.0023)\end{array}$ & $\begin{array}{l}0.0012 \\
(0.0023)\end{array}$ \\
\hline$\lambda$ & $\begin{array}{l}-0.0135 \\
(0.0124)\end{array}$ & $\begin{array}{l}-0.0145 \\
(0.0124)\end{array}$ & $\begin{array}{l}-0.0175 \\
(0.0124)\end{array}$ & $\begin{array}{l}-0.0200 \\
(0.0123)\end{array}$ & $\begin{array}{l}-0.0350 * \\
(0.0200)\end{array}$ & $\begin{array}{l}-0.0351 * \\
(0.0201)\end{array}$ \\
\hline Year dummies & $p$-val. $<0.001$ & $p$-val. $<0.001$ & $p$-val. $<0.001$ & $p$-val. $<0.001$ & $p$-val. $<0.001$ & $p$-val. $<0.001$ \\
\hline Constant & $\begin{array}{l}1.0460 * * * \\
(0.0509)\end{array}$ & $\begin{array}{l}1.0321^{* * *} \\
(0.0510)\end{array}$ & $\begin{array}{l}1.0590 * * * \\
(0.0484)\end{array}$ & $\begin{array}{l}1.0602 * * * \\
(0.0506)\end{array}$ & $\begin{array}{l}1.1624^{* * *} \\
(0.0365)\end{array}$ & $\begin{array}{l}1.1584^{* * *} \\
(0.0366)\end{array}$ \\
\hline$R^{2}$ overall model & 0.329 & 0.327 & 0.331 & 0.330 & 0.326 & 0.324 \\
\hline
\end{tabular}




\begin{tabular}{|c|c|c|c|c|c|c|}
\hline & $\begin{array}{l}\text { RE G2SLS } \\
\text { Full sample }\end{array}$ & $\begin{array}{l}\text { RE G2SLS } \\
\text { Full sample }\end{array}$ & $\begin{array}{l}\text { RE G2SLS } \\
\text { No liberal } \\
\text { professionals }\end{array}$ & $\begin{array}{l}\text { RE G2SLS } \\
\text { No liberal } \\
\text { professionals }\end{array}$ & $\begin{array}{l}\text { RE } \\
\text { Full sample }\end{array}$ & $\begin{array}{l}\text { RE } \\
\text { Full sample }\end{array}$ \\
\hline \multicolumn{7}{|l|}{ educ: } \\
\hline $1^{\text {st }}$ stage $F$ stat. & 2616.554 & 3927.501 & 2480.344 & 3658.618 & & \\
\hline Shea's Partial $R^{2}$ & 0.093 & 0.093 & 0.091 & 0.090 & & \\
\hline \multicolumn{7}{|c|}{$1^{\text {st }}$ interact. term: } \\
\hline $1^{\text {st }}$ stage $F$ stat. & 4144.514 & 6196.751 & 2923.589 & 4239.917 & & \\
\hline Shea's Partial $R^{2}$ & 0.139 & 0.139 & 0.106 & 0.103 & & \\
\hline \multicolumn{7}{|l|}{$2^{\text {nd }}$ interact. term: } \\
\hline $1^{\text {st }}$ stage $F$ stat. & 4308.837 & & 2588.610 & & & \\
\hline Shea's Partial $R^{2}$ & 0.142 & & 0.093 & & & \\
\hline Person-year obs. & 78371 & 78371 & 76010 & 76010 & 82364 & 82364 \\
\hline \multicolumn{7}{|c|}{$\begin{array}{l}\text { Notes: Random effects G2SLS estimations (first four columns) with endogenous variables educ and its } \\
\text { interactions with oppEntre and necEntre; excluded instruments: father's education and its two interactions. F- } \\
\text { statistics at the bottom of the table refer to first stage tests of joint significance of the excluded instruments. } \lambda \text { is } \\
\text { the selection correction term. In the row of the year dummies, the } p \text {-values refer to } F \text {-tests of joint significance. } \\
\text { Definitions of the variables appear in Table A } 1 . * / * * / * * * \text { Significance at the } 10 \% / 5 \% / 1 \% \text { level. } \\
\text { Source: Authors' calculations based on SOEPv27, } 1998-2010 \text {. }\end{array}$} \\
\hline
\end{tabular}

The first stage statistics indicate that the instruments are sufficiently relevant. For the endogenous variables (education and its interactions with the opportunity and necessity entrepreneur dummies or the self-employment dummy, respectively), the first stage $F$ statistics of the excluded instruments and Shea's Partial $R^{2}$ are shown at the bottom of the table. $^{32}$ The Hausman (1978) test rejects exogeneity of the variables treated as endogenous in the first column ( $p$-value below 0.001). We therefore expect OLS or random effects estimators without IV to be inconsistent. For comparison, we nevertheless present the results from the usual random effects (RE) estimator in the two rightmost columns. The coefficient of the returns to education for employees is biased downward by more than one percentage point, as common in the literature on the returns to education; the reason may be attenuation bias due to measurement error in the education variable. The biased estimates do not show significantly higher returns for opportunity entrepreneurs than for paid employees; the returns for necessity entrepreneurs are still significantly lower than for employees, but the difference is smaller. The global estimate for the self-employed is not significantly different from the estimate for paid employees when endogeneity of education is not accounted for.

\footnotetext{
${ }^{32}$ Full results for all first stage and selection equations are available from the authors on request.
} 
We revisit the consistent estimates in the first two columns to briefly inspect the coefficients of the control variables and the selection term $\lambda_{i t}$. The estimated coefficients of the control variables are consistent with expectations. Work experience increases earnings at diminishing rates, whereas unemployment experience decreases earnings; this is in line with human capital theory and human capital depreciation. Women and people living in eastern Germany have lower earnings. Interestingly, higher scores in agreeableness and neuroticism decrease and a more internal locus of control increases earnings. ${ }^{33}$ The coefficient of $\lambda_{i t}$ is insignificant, so there is no indication for selection based on unobservables, whereas in the random effects estimation without IV, $\lambda_{i t}$. is significant at the $10 \%$-level.

In additional specifications, we assess the sensitivity of the results with respect to the exclusion of liberal professionals, i.e. mostly academic professions among the self-employed like physicians, lawyers, architects, journalists, and artists. Applying the consistent G2SLS estimator to the sample without liberal professionals, we obtain results that are very similar to the baseline estimation with regard to the returns to education of opportunity and necessity entrepreneurs (columns 3 and 4). However, the global estimate for the self-employed is no longer significantly different from the estimate for paid employees. As mentioned, some authors in labour economics report lower returns for the self-employed than for paid employees in other countries and attribute this to the absence of the signalling value of education for the self-employed; they often exclude liberal professionals from their samples, which may partly explain their low estimated returns (e.g. Wolpin, 1977).

Table 4 presents the results from G2SLS estimations of equation (2) separately for paid employees, opportunity and necessity entrepreneurs, controlling for non-random selection into each of the three states. The results are consistent with the baseline joint estimation reported

\footnotetext{
${ }^{33}$ The eight personality variables are standardized before estimation, so the coefficients conveniently express the percentage change in earnings if a personality score increases by one standard deviation. The results with respect to education remain very similar if the personality variables are excluded from the model (available from the authors on request).
} 
in column 1 of Table 3. The return to education for paid employees is estimated at $8.1 \%$ again, opportunity entrepreneurs have a higher point estimate of $13.9 \%$ (both are significant), ${ }^{34}$ and necessity entrepreneurs have a much lower point estimate of $3.0 \%$, which again is not significantly different from zero. The selection correction term $\lambda_{i t j}$ is significant at the 10\%-level for necessity entrepreneurs, but not for paid employees and opportunity entrepreneurs. Self-selection into opportunity entrepreneurship based on unobservables therefore does not seem to be relevant for the estimation. While the significant coefficient of $\lambda_{i t, \text { necessity entrepreneur }}$ suggests that non-random selection into necessity entrepreneurship should not be ignored from a statistical standpoint, the point estimate for the returns to education are similar to those in Table 3 and thus provide no indication for an important selection bias. Constraining the coefficients of the control variables to be the same for the different groups as done in Table 3, but not in Table 4, also does not seem to influence the results with respect to education. In sum, our preferred specification is equation (1) as shown in the first column of Table 3 for the ease of comparisons between the groups.

\footnotetext{
${ }^{34}$ While the point estimate for opportunity entrepreneurs is higher here (13.9\%) than in the baseline estimation $(8.1 \%+3.5 \%=11.6 \%)$, the estimates are not statistically different from each other considering the standard errors.
} 
Table 4: Separate RE G2SLS earnings regressions with general definition of entrepreneurial types

\begin{tabular}{|c|c|c|c|}
\hline & Paid employees & "Opportunity entrepreneurs & "Necessity entrepreneurs \\
\hline \multirow[t]{2}{*}{ educ } & $0.0809 * * *$ & $0.1388 * * *$ & 0.0297 \\
\hline & $(0.0044)$ & $(0.0357)$ & $(0.0613)$ \\
\hline \multirow[t]{2}{*}{ workExp } & $0.0424 * * *$ & $0.0396 * * *$ & 0.0327 \\
\hline & $(0.0013)$ & $(0.0105)$ & $(0.0232)$ \\
\hline \multirow[t]{2}{*}{ workExp squared } & $-0.0061 * * *$ & $-0.0040^{* * *}$ & -0.0005 \\
\hline & $(0.0002)$ & $(0.0013)$ & $(0.0036)$ \\
\hline \multirow[t]{2}{*}{ unemplExp } & $-0.0775 * * *$ & $-0.0691 * *$ & -0.0558 \\
\hline & $(0.0027)$ & $(0.0337)$ & $(0.0356)$ \\
\hline \multirow[t]{2}{*}{ age } & $-0.0070 * * *$ & $-0.0122 *$ & -0.0193 \\
\hline & $(0.0010)$ & $(0.0074)$ & $(0.0187)$ \\
\hline \multirow[t]{2}{*}{ female } & $-0.2068 * * *$ & $-0.2241 * * *$ & $-0.2611 * *$ \\
\hline & $(0.0078)$ & $(0.0542)$ & $(0.1023)$ \\
\hline \multirow[t]{2}{*}{ west } & $0.2905 * * *$ & $0.4170^{* * *}$ & $0.5183^{* * *}$ \\
\hline & $(0.0081)$ & $(0.0620)$ & $(0.1038)$ \\
\hline \multirow[t]{2}{*}{ partner } & $0.0347 * * *$ & -0.0307 & -0.0091 \\
\hline & $(0.0049)$ & $(0.0387)$ & $(0.0814)$ \\
\hline \multirow[t]{2}{*}{ children } & 0.0062 & 0.0402 & 0.1118 \\
\hline & $(0.0040)$ & $(0.0325)$ & $(0.0718)$ \\
\hline \multirow[t]{2}{*}{ handicapped } & $-0.0337 * * *$ & $-0.1302 *$ & 0.0955 \\
\hline & $(0.0083)$ & $(0.0767)$ & $(0.1503)$ \\
\hline \multirow[t]{2}{*}{ migrant } & $0.0186^{*}$ & 0.0709 & -0.0497 \\
\hline & $(0.0110)$ & $(0.0741)$ & $(0.1388)$ \\
\hline \multirow[t]{2}{*}{ openness } & 0.0034 & $-0.0488 * *$ & -0.0627 \\
\hline & $(0.0030)$ & $(0.0226)$ & $(0.0490)$ \\
\hline \multirow[t]{2}{*}{ conscientiousness } & 0.0025 & 0.0197 & -0.0630 \\
\hline & $(0.0028)$ & $(0.0187)$ & $(0.0400)$ \\
\hline \multirow{2}{*}{ extraversion } & $-0.0067 * *$ & $0.0401 *$ & -0.0141 \\
\hline & $(0.0029)$ & $(0.0216)$ & $(0.0442)$ \\
\hline \multirow[t]{2}{*}{ agreeableness } & $-0.0091 * * *$ & $-0.0380 * *$ & $0.0887 * *$ \\
\hline & $(0.0027)$ & $(0.0190)$ & $(0.0377)$ \\
\hline \multirow[t]{2}{*}{ neuroticism } & $-0.0117 * * *$ & $-0.0369 *$ & -0.0185 \\
\hline & $(0.0028)$ & $(0.0189)$ & $(0.0400)$ \\
\hline \multirow[t]{2}{*}{ internal locus } & 0.0027 & $0.0418^{*}$ & $0.1141^{* * *}$ \\
\hline & $(0.0029)$ & $(0.0245)$ & $(0.0418)$ \\
\hline \multirow[t]{2}{*}{ external locus } & $-0.0375 * * *$ & $-0.0549 * *$ & 0.0242 \\
\hline & $(0.0034)$ & $(0.0213)$ & $(0.0426)$ \\
\hline \multirow[t]{2}{*}{ risk tolerance } & -0.0002 & 0.0257 & -0.0084 \\
\hline & $(0.0019)$ & $(0.0204)$ & $(0.0378)$ \\
\hline \multirow[t]{2}{*}{$\lambda$} & -0.0087 & 0.0056 & $-0.3152 *$ \\
\hline & $(0.0102)$ & $(0.1156)$ & $(0.1733)$ \\
\hline Year dummies & $p$-value $<0.001$ & $p$-value $<0.001$ & $p$-value $=0.097$ \\
\hline \multirow[t]{2}{*}{ Constant } & $1.0527 * * *$ & 0.0374 & $2.4203 * * *$ \\
\hline & $(0.0476)$ & $(0.6122)$ & $(0.8222)$ \\
\hline$R^{2}$ for overall model & 0.371 & 0.179 & 0.187 \\
\hline $1^{\text {st }}$ stage $F$ stat. & 7035.156 & 316.907 & 75.283 \\
\hline Shea's Partial $R^{2}$ & 0.090 & 0.051 & 0.074 \\
\hline Person-year obs. & 71446 & 5950 & 975 \\
\hline
\end{tabular}

Notes: Random effects G2SLS estimations with endogenous variable educ; excluded instrument: father's education. $F$-statistics at the bottom of the table refer to first stage tests of significance of the excluded instrument. $\lambda$ is the selection correction term. In the row of the year dummies, the $p$-values refer to $F$-tests of joint significance. $* / * * / * * *$ : Significance at the $10 \% / 5 \% / 1 \%$ level.

Source: Authors' calculations based on SOEPv27, 1998-2010. 


\subsection{Results for the more specific definition of entrepreneurial types}

To assess the sensitivity of the results with respect to the operationalisation of opportunity and necessity entrepreneurs, we repeat the estimations using the alternative classification scheme, which exploits the way the previous wage job was terminated, based on the sub-sample where such information are available (see Section 2.3). The results from estimating equation (1) appear in Table 5. Column 1 shows the G2SLS random effects IV estimation results, column 2 excludes liberal professionals from the sample, and column 3 provides the results from a RE estimation not accounting for the potential endogeneity of education (again including liberal professionals). The estimated returns to education for paid employees in column 1 are similar to those in column 1 of Table 3 using the baseline classification scheme. The returns to education of opportunity entrepreneurs are not significantly different from those of paid employees when using this alternative classification, however. The coefficient of the interaction term educ $x$ oppEntre is estimated imprecisely, as indicated by its standard error which is larger than in Table 3, presumably because of the exclusion of self-employed persons who could not be classified using this scheme. Necessity entrepreneurs still have significantly lower returns to education than paid employees, albeit the discount is not as large as in Table 3. In this specification, the Hausman test of endogeneity does not reject exogeneity of education and its interactions $(p$-value $=0.441) .{ }^{35}$ The random effects estimator in column 3 is therefore expected to be consistent in this case and is then preferred because of its higher efficiency. Here, the point estimate of the gap in the returns to education between paid employees and necessity entrepreneurs is larger. ${ }^{36}$ The returns to education are significantly smaller for necessity than for opportunity entrepreneurs based on the RE estimator ( $p$-value = 0.048), and also in column 2 where liberal professionals are excluded ( $p$-value $=0.072)$.

\footnotetext{
${ }^{35}$ The first stage statistics provided at the bottom of the table again indicate that the instruments are sufficiently relevant. The selection correction terms are statistically significant in all columns.

${ }^{36}$ The returns to education of necessity entrepreneurs are significantly different from zero ( $p$-value $=0.048$ ). When liberal professionals are excluded (column 2), the returns of necessity entrepreneurs are not significantly different from zero.
} 
Table 5: Joint earnings regressions with specific definition of entrepreneurial types

\begin{tabular}{|c|c|c|c|}
\hline & $\begin{array}{l}\text { RE G2SLS } \\
\text { Full sample }\end{array}$ & $\begin{array}{l}\text { RE G2SLS } \\
\text { No liberal professionals }\end{array}$ & $\begin{array}{l}\text { RE } \\
\text { Full sample }\end{array}$ \\
\hline educ & $\begin{array}{l}0.0790 * * * \\
(0.0046)\end{array}$ & $\begin{array}{l}0.0787 * * * \\
(0.0046)\end{array}$ & $\begin{array}{l}0.0702 * * * \\
(0.0022)\end{array}$ \\
\hline educ x oppEntre & $\begin{array}{l}-0.0077 \\
(0.0131)\end{array}$ & $\begin{array}{l}-0.0232 \\
(0.0212)\end{array}$ & $\begin{array}{l}-0.0037 \\
(0.0114)\end{array}$ \\
\hline educ $x$ necEntre & $\begin{array}{l}-0.0372^{* *} \\
(0.0167)\end{array}$ & $\begin{array}{l}-0.0830^{* * *} \\
(0.0260)\end{array}$ & $\begin{array}{l}-0.0486 * * \\
(0.0201)\end{array}$ \\
\hline oppEntre & $\begin{array}{l}0.0529 \\
(0.1787)\end{array}$ & $\begin{array}{l}0.2151 \\
(0.2671)\end{array}$ & $\begin{array}{l}0.0145 \\
(0.1637)\end{array}$ \\
\hline necEntre & $\begin{array}{l}0.3286 \\
(0.2238)\end{array}$ & $\begin{array}{l}0.8770 * * * \\
(0.3336)\end{array}$ & $\begin{array}{l}0.4928 * \\
(0.2717)\end{array}$ \\
\hline workExp & $\begin{array}{l}0.0403 * * * \\
(0.0014)\end{array}$ & $\begin{array}{l}0.0401 * * * \\
(0.0014)\end{array}$ & $\begin{array}{l}0.0386^{* * *} \\
(0.0018)\end{array}$ \\
\hline workExp squared & $\begin{array}{l}-0.0059^{* * *} \\
(0.0002)\end{array}$ & $\begin{array}{l}-0.0058^{* * *} \\
(0.0002)\end{array}$ & $\begin{array}{l}-0.0057 * * * \\
(0.0003)\end{array}$ \\
\hline unemplExp & $\begin{array}{l}-0.0722^{* * *} \\
(0.0028)\end{array}$ & $\begin{array}{l}-0.0717^{* * *} \\
(0.0028)\end{array}$ & $\begin{array}{l}-0.0768^{* * *} \\
(0.0054)\end{array}$ \\
\hline age & $\begin{array}{l}-0.0060^{* * *} \\
(0.0011)\end{array}$ & $\begin{array}{l}-0.0059 * * * \\
(0.0011)\end{array}$ & $\begin{array}{l}-0.0050^{* * *} \\
(0.0013)\end{array}$ \\
\hline female & $\begin{array}{l}-0.2027 * * * \\
(0.0079)\end{array}$ & $\begin{array}{l}-0.2024^{* * *} \\
(0.0079)\end{array}$ & $\begin{array}{l}-0.2009 * * * \\
(0.0085)\end{array}$ \\
\hline west & $\begin{array}{l}0.2936 * * * \\
(0.0083)\end{array}$ & $\begin{array}{l}0.2936 * * * \\
(0.0083)\end{array}$ & $\begin{array}{l}0.2787 * * * \\
(0.0122)\end{array}$ \\
\hline partner & $\begin{array}{l}0.0340 * * * \\
(0.0050)\end{array}$ & $\begin{array}{l}0.0346 * * * \\
(0.0050)\end{array}$ & $\begin{array}{l}0.0316^{* * *} \\
(0.0066)\end{array}$ \\
\hline children & $\begin{array}{l}0.0112 * * * \\
(0.0041)\end{array}$ & $\begin{array}{l}0.0096^{* *} \\
(0.0041)\end{array}$ & $\begin{array}{l}0.0114^{* *} \\
(0.0054)\end{array}$ \\
\hline handicapped & $\begin{array}{l}-0.0299 * * * \\
(0.0086)\end{array}$ & $\begin{array}{l}-0.0326^{* * *} \\
(0.0086)\end{array}$ & $\begin{array}{l}-0.0287 * * \\
(0.0115)\end{array}$ \\
\hline migrant & $\begin{array}{l}0.0220^{*} \\
(0.0113)\end{array}$ & $\begin{array}{l}0.0202 * \\
(0.0112)\end{array}$ & $\begin{array}{l}0.0178 \\
(0.0118)\end{array}$ \\
\hline openness & $\begin{array}{l}0.0038 \\
(0.0030)\end{array}$ & $\begin{array}{l}0.0039 \\
(0.0030)\end{array}$ & $\begin{array}{l}0.0043 \\
(0.0032)\end{array}$ \\
\hline conscientiousness & $\begin{array}{l}0.0016 \\
(0.0029)\end{array}$ & $\begin{array}{l}0.0010 \\
(0.0029)\end{array}$ & $\begin{array}{l}0.0019 \\
(0.0033)\end{array}$ \\
\hline extraversion & $\begin{array}{l}-0.0072 * * \\
(0.0030)\end{array}$ & $\begin{array}{l}-0.0068 * * \\
(0.0030)\end{array}$ & $\begin{array}{l}-0.0065^{*} \\
(0.0034)\end{array}$ \\
\hline agreeableness & $\begin{array}{l}-0.0083 * * * \\
(0.0028)\end{array}$ & $\begin{array}{l}-0.0079 * * * \\
(0.0028)\end{array}$ & $\begin{array}{l}-0.0065^{* *} \\
(0.0033)\end{array}$ \\
\hline neuroticism & $\begin{array}{l}-0.0109 * * * \\
(0.0028)\end{array}$ & $\begin{array}{l}-0.0117 * * * \\
(0.0028)\end{array}$ & $\begin{array}{l}-0.0099 * * * \\
(0.0032)\end{array}$ \\
\hline internal locus & $\begin{array}{l}0.0034 \\
(0.0030)\end{array}$ & $\begin{array}{l}0.0033 \\
(0.0030)\end{array}$ & $\begin{array}{l}0.0016 \\
(0.0032)\end{array}$ \\
\hline external locus & $\begin{array}{l}-0.0375^{* * *} \\
(0.0035)\end{array}$ & $\begin{array}{l}-0.0379 * * * \\
(0.0034)\end{array}$ & $\begin{array}{l}-0.0355^{* * *} \\
(0.0035)\end{array}$ \\
\hline risk tolerance & $\begin{array}{l}-0.0006 \\
(0.0020)\end{array}$ & $\begin{array}{l}-0.0008 \\
(0.0020)\end{array}$ & $\begin{array}{l}-0.0007 \\
(0.0021)\end{array}$ \\
\hline$\lambda$ & $\begin{array}{l}-0.0426 * * * \\
(0.0111)\end{array}$ & $\begin{array}{l}-0.0416^{* * *} \\
(0.0111)\end{array}$ & $\begin{array}{l}-0.0548 * * * \\
(0.0193)\end{array}$ \\
\hline Year dummies & $p$-value $<0.001$ & $p$-value $<0.001$ & $p$-value $<0.001$ \\
\hline Constant & $\begin{array}{l}1.0524 * * * \\
(0.0485)\end{array}$ & $\begin{array}{l}1.0574 * * * \\
(0.0485)\end{array}$ & $\begin{array}{l}1.1524 * * * \\
(0.0358)\end{array}$ \\
\hline $\begin{array}{l}R^{2} \text { for overall model } \\
\text { educ: }\end{array}$ & 0.357 & 0.360 & 0.352 \\
\hline $\begin{array}{l}1^{\text {st }} \text { stage } F \text { stat. } \\
\text { Shea’s Partial } R^{2}\end{array}$ & $\begin{array}{l}2380.044 \\
0.089\end{array}$ & $\begin{array}{l}2327.725 \\
0.088\end{array}$ & \\
\hline
\end{tabular}




\begin{tabular}{clll}
\hline \hline & $\begin{array}{l}\text { RE G2SLS } \\
\text { Full sample }\end{array}$ & $\begin{array}{l}\text { RE G2SLS } \\
\text { No liberal professionals }\end{array}$ & $\begin{array}{l}\text { RE } \\
\text { Full sample }\end{array}$ \\
\hline Interact. with oppEntre: & & & \\
$1^{\text {st }}$ stage $F$ stat. & 4373.532 & 3080.595 & \\
Shea's Partial $R^{2}$ & 0.153 & 0.113 & \\
Interact. with necEntre: & & & \\
$1^{\text {st }}$ stage $F$ stat. & 4379.222 & 2514.679 & \\
Shea's Partial $R^{2}$ & 0.152 & 0.094 & 77148 \\
Person-year obs. & 73429 & 72796 & \\
\hline
\end{tabular}

Notes: Random effects G2SLS estimations (first two columns) with endogenous variables educ and its interactions with oppEntre and necEntre; excluded instruments: father's education and its two interactions. $F$-statistics at the bottom of the table refer to first stage tests of joint significance of the excluded instruments. $\lambda$ is the selection correction term. In the row of the year dummies, the $p$-values refer to $F$-tests of joint significance. $* / * * / * * *$ : Significance at the $10 \% / 5 \% / 1 \%$ level.

Source: Authors' calculations based on SOEPv27, 1998-2010.

As before, we also estimate equation (2) separately for paid employees, opportunity and necessity entrepreneurs, which enables us to control for non-random selection into each of these states. Table 6 shows that the point estimates of the returns to education in the three groups are similar to those in Table 4 using the baseline classification scheme, with a higher point estimate for opportunity entrepreneurs than for paid employees and a lower one for necessity entrepreneurs. Because of the lower number of self-employed observations after excluding those who could not be classified, however, the standard errors are large and the coefficients for the two types of entrepreneurs are no longer statistically significant.

In summary, using the alternative operationalisation of the two entrepreneurial types, the evidence again supports hypotheses 1 and 3 (this is statistically significant in Table 5), whereas in this robustness check no conclusion can be drawn about the returns to education of opportunity entrepreneurs relative to paid employees (hypothesis 2) due to the lower precision of the relevant coefficients. 
Table 6: Separate RE G2SLS earnings regressions with specific definition of entrepreneurial types

\begin{tabular}{|c|c|c|c|}
\hline & Paid employees & "Opportunity entrepreneurs & "Necessity entrepreneurs \\
\hline \multirow[t]{2}{*}{ educ } & $0.0804 * * *$ & 0.1152 & 0.0311 \\
\hline & $(0.0045)$ & $(0.0775)$ & $(0.0898)$ \\
\hline \multirow[t]{2}{*}{ workExp } & $0.0417 * * *$ & 0.0387 & 0.0403 \\
\hline & $(0.0013)$ & $(0.0320)$ & $(0.0342)$ \\
\hline \multirow[t]{2}{*}{ workExp squared } & $-0.0060 * * *$ & -0.0051 & -0.0046 \\
\hline & $(0.0002)$ & $(0.0032)$ & $(0.0042)$ \\
\hline \multirow[t]{2}{*}{ unemplExp } & $-0.0767 * * *$ & -0.0621 & -0.0435 \\
\hline & $(0.0027)$ & $(0.0610)$ & $(0.0433)$ \\
\hline \multirow[t]{2}{*}{ age } & $-0.0066 * * *$ & -0.0109 & -0.0145 \\
\hline & $(0.0010)$ & $(0.0279)$ & $(0.0306)$ \\
\hline \multirow[t]{2}{*}{ female } & $-0.2059 * * *$ & $-0.3511 * * *$ & $-0.2852 * *$ \\
\hline & $(0.0078)$ & $(0.1168)$ & $(0.1292)$ \\
\hline \multirow[t]{2}{*}{ west } & $0.2894 * * *$ & $0.4013^{* * *}$ & $0.4105^{* * *}$ \\
\hline & $(0.0081)$ & $(0.1355)$ & $(0.1260)$ \\
\hline \multirow[t]{2}{*}{ partner } & $0.0349 * * *$ & -0.0260 & 0.0261 \\
\hline & $(0.0049)$ & $(0.0729)$ & $(0.1009)$ \\
\hline \multirow[t]{2}{*}{ children } & $0.0073^{*}$ & $0.1104^{*}$ & 0.0940 \\
\hline & $(0.0040)$ & $(0.0581)$ & $(0.0886)$ \\
\hline \multirow[t]{2}{*}{ handicapped } & $-0.0327 * * *$ & 0.1839 & 0.0750 \\
\hline & $(0.0083)$ & $(0.1702)$ & $(0.1691)$ \\
\hline \multirow[t]{2}{*}{ migrant } & $0.0189 *$ & 0.2103 & -0.0791 \\
\hline & $(0.0110)$ & $(0.1533)$ & (0.1789) \\
\hline \multirow[t]{2}{*}{ openness } & 0.0033 & 0.0051 & -0.0151 \\
\hline & $(0.0030)$ & $(0.0459)$ & $(0.0593)$ \\
\hline \multirow[t]{2}{*}{ conscientiousness } & 0.0022 & 0.0066 & 0.0118 \\
\hline & $(0.0028)$ & $(0.0421)$ & $(0.0507)$ \\
\hline \multirow{2}{*}{ extraversion } & $-0.0067 * *$ & 0.0137 & 0.0061 \\
\hline & $(0.0029)$ & $(0.0438)$ & $(0.0556)$ \\
\hline \multirow[t]{2}{*}{ agreeableness } & $-0.0090 * * *$ & -0.0264 & 0.0332 \\
\hline & $(0.0027)$ & $(0.0421)$ & $(0.0484)$ \\
\hline \multirow[t]{2}{*}{ neuroticism } & $-0.0115 * * *$ & 0.0259 & -0.0121 \\
\hline & $(0.0028)$ & $(0.0425)$ & $(0.0492)$ \\
\hline \multirow[t]{2}{*}{ internal locus } & 0.0026 & 0.0712 & $0.1027^{*}$ \\
\hline & $(0.0029)$ & $(0.0488)$ & $(0.0593)$ \\
\hline \multirow[t]{2}{*}{ external locus } & $-0.0371 * * *$ & -0.0289 & -0.0311 \\
\hline & $(0.0034)$ & $(0.0471)$ & $(0.0520)$ \\
\hline \multirow[t]{2}{*}{ risk tolerance } & -0.0002 & 0.0393 & -0.0499 \\
\hline & $(0.0019)$ & $(0.0354)$ & $(0.0422)$ \\
\hline \multirow[t]{2}{*}{$\lambda$} & $-0.0203^{* *}$ & -0.0372 & -0.0311 \\
\hline & $(0.0103)$ & $(0.1442)$ & (0.1939) \\
\hline Year dummies & $p$-value $<0.001$ & $p$-value $<0.001$ & $p$-value $=0.099$ \\
\hline \multirow[t]{2}{*}{ Constant } & $1.0544 * * *$ & 0.1973 & 1.4407 \\
\hline & $(0.0476)$ & $(0.7608)$ & $(0.9502)$ \\
\hline$R^{2}$ for overall model & 0.371 & 0.193 & 0.145 \\
\hline $1^{\text {st }}$ stage $F$ stat. & 6949.640 & 68.304 & 40.782 \\
\hline Shea's Partial $R^{2}$ & 0.089 & 0.052 & 0.057 \\
\hline Person-year obs. & 71446 & 1278 & 705 \\
\hline
\end{tabular}

Notes: Random effects G2SLS estimations with endogenous variable educ; excluded instrument: father's education. $F$-statistics at the bottom of the table refer to first stage tests of significance of the excluded instrument. $\lambda$ is the selection correction term. In the row of the year dummies, the $p$-values refer to $F$-tests of joint significance. $* / * * / * * *$ : Significance at the $10 \% / 5 \% / 1 \%$ level.

Source: Authors' calculations based on SOEPv27, 1998-2010. 


\section{Conclusion}

We estimate the returns to education for opportunity entrepreneurs, who voluntarily become entrepreneurs because they spot a business opportunity; for necessity entrepreneurs, who are pushed into entrepreneurship because they lack alternative employment options; and for paid employees, who provide a benchmark. We use representative household panel data for Germany, the SOEP, and account for the endogeneity of education and non-random selection into the different employment states. The results from the preferred specification indicate that the returns to an additional year of education are 3.5 percentage points higher for opportunity entrepreneurs than for paid employees, whose rate of return is estimated at $8.1 \%$, and as much as 6.5 percentage points lower for necessity entrepreneurs.

These results confirm our hypotheses, which we derive from our extension of the theory of personal control. According to the original theory (Douhan and Van Praag, 2009), entrepreneurs should enjoy higher returns to education than paid employees, because they have better control over the employment of and the accruals from their own human capital. We argue that this only applies to opportunity entrepreneurs, while the fact that necessity entrepreneurs cannot find employment at the labour market indicates that they have only limited control over the employment of their human capital. This is one of the reasons why it is crucial to distinguish between the two types of entrepreneurs when estimating entrepreneurial returns to education.

When pooling opportunity and necessity entrepreneurs, as done in the prior literature, the single estimate of the returns to a year of education (we estimate an average 1.9 percentage points premium over paid employees in Germany) understates the value of formal education for those who become entrepreneurs because they spot a business opportunity. This paper shows that education policy can play a much more important role when governments intend to stimulate opportunity entrepreneurship than the prior literature suggested. At the same time, 
the pooled estimate of returns to education averaged over the two entrepreneurial types may spark misguided hopes concerning necessity entrepreneurs, who may, for example, receive public start-up subsidies in the vainly expectation that becoming an entrepreneur will allow them to use their education productively.

This analysis also provides a possible explanation for country differences in entrepreneurial returns to education. In their meta-analysis, Van der Sluis et al. (2008) speculate that higher entrepreneurial returns to education in the US in comparison to the European countries, where studies were available (the UK, Italy, and the Netherlands), could be due to different abilities of the educational systems to prepare the countries' citizens for entrepreneurial activity (although the econometric shortcomings in the extant studies highlighted by Van der Sluis et al. constitute a limitation to this comparison). Combining this explanation with Lazear’s (2004) “jack-of-all-trades” view of entrepreneurs, this could imply that the educational system in the US is more successful in teaching the general skills entrepreneurs need to cope with their wide spectrum of responsibilities, while European education may tend to create specialists who do better as employees (see also Doms et al., 2010). However, the large differences in the returns to education for opportunity versus necessity entrepreneurs found in this study suggest that different shares of necessity and opportunity entrepreneurs in a country's total set of entrepreneurs may explain an important part of the country differences in the average returns to education of the self-employed. Brixy et al. (2011) demonstrate that the ratio between opportunity and necessity entrepreneurs varies widely between countries. Figure 1 shows that necessity entrepreneurship was more prevalent in Germany than in the US before the financial and economic crisis, so average returns to education for entrepreneurs might have been lower in Germany even if the educational systems did not have different effects. These differences in the composition of entrepreneurs may have reasons unrelated to the quality of education; for instance, tighter labour market 
regulation may push people into necessity entrepreneurship if this creates barriers to obtaining paid employment.

Finally, the heterogeneity between opportunity and necessity entrepreneurs casts further doubt on the use of the self-employed as a control group to test the signalling theory, because the lower returns to education of necessity entrepreneurs - which decrease the average rate of return for the self-employed - are not due to the absence of signalling toward employers (in this respect they do not differ from opportunity entrepreneurs), but due to their inability to use the productivity enhancing function of their education. We substantiate this explanation by demonstrating that a smaller share of necessity entrepreneurs report that they are working in the profession they were trained for than both paid employees and opportunity entrepreneurs.

\section{References}

Almlund, Mathilde, Angela Lee Duckworth, James J. Heckman and Tim D. Kautz (2011). 'Personality Psychology and Economics', in: Eric A. Hanushek, Stephen Machin and Ludger Woessmann (eds.), Handbook of the Economics of Education, Volume 4, Amsterdam: Elsevier, 1-181.

Angrist, Joshua D. and Alan B. Krueger (1991). 'Does Compulsory School Attendance Affect Schooling and Earnings?’, Quarterly Journal of Economics 106(4), 979-1014.

Ardagna, Silvia and Annamaria Lusardi (2009): 'Where Does Regulation Hurt? Evidence from New Businesses across Countries', NBER Working Paper 14747, National Bureau of Economic Research.

Arulampalam, Wiji (2008). 'Is Unemployment Really Scarring? Effects of Unemployment Experiences on Wages’, Economic Journal 111(475), 585-606.

Ashenfelter, Orley, Colm Harmon and Hessel Oosterbeek (1999). 'A Review of Estimates of the Schooling/Earnings Relationship, with Tests for Publication Bias', Labour Economics 6(4), 453-470.

Balestra, Pietro and Varadharajan-Krishnakumar, Jayalakshmi (1987). 'Full Information Estimations of a System of Simultaneous Equations with Error Component Structure', Econometric Theory 3, 223-246. 
Backes Gellner, Uschi and Arndt Werner (2007). 'Entrepreneurial Signaling via Education: A Success Factor in Innovative Start Ups’, Small Business Economics 29, 173-190.

Becker, Gary S. (1962). 'Investment in Human Capital: A Theoretical Analysis', Economic Journal 75, 493-513.

Benz, Matthias and Bruno S. Frey (2008). 'Being Independent is a Great Thing: Subjective Evaluations of Self-employment and Hierarchy', Economica 75, 362-383.

Block, Joern, Lennart F. Hoogerheide and Roy Thurik (2010). 'Are Education and Entrepreneurial Income Endogenous and Do Family Background Variables Make Sense as Instruments? A Bayesian Analysis', SOEPpapers on Multidisciplinary Panel Data Research 329, German Institute for Economic Research (DIW Berlin).

Block, Joern and Marcus Wagner (2010). 'Necessity and Opportunity Entrepreneurs in Germany: Characteristics and Earnings Differentials', Schmalenbach Business Review 62, 154-174.

Bound, John, David Jaeger and Regina M. Baker (1995). 'Problems with Instrumental Variables Estimation When the Correlation between the Instruments and Endogenous Explanatory Variables Is Weak', Journal of the American Statistical Association 90, 443450.

Brixy, Udo, Christian Hundt, Rolf Sternberg and Arne Vorderwülbecke (2011). 'Global Entrepreneurship Monitor (GEM): Länderbericht Deutschland 2010’ (Country Report Germany 2010), University of Hanover and Institute for Employment Research (IAB), Nuremberg.

Brown, Sarah and John G. Sessions (1999). 'Education and Employment Status: A Test of the Strong Screening Hypothesis for Italy', Economics of Education Review 18, 397-404.

Caliendo, Marco, Frank M. Fossen and Alexander S. Kritikos (2009). 'Risk Attitudes of Nascent Entrepreneurs - New Evidence from an Experimentally-Validated Survey', Small Business Economics 32(2), 153-167.

Caliendo, Marco, Frank M. Fossen and Alexander S. Kritikos (2010). 'The Impact of Risk Attitudes on Entrepreneurial Survival', Journal of Economic Behavior and Organization 76, 45-63.

Caliendo, Marco, Frank M. Fossen and Alexander S. Kritikos (2011). 'Personality Characteristics and the Decision to Become and Stay Self-Employed', IZA Discussion Paper 5566, Institute for the Study of Labor.

Caliendo, Marco and Steffen Künn (2011). 'Start-up subsidies for the unemployed: Long-term evidence and effect heterogeneity', Journal of Public Economics 95(3-4), 311-331. 
Card, David E. (1999). 'The Causal Effect of Education on Earnings', in: Orley Ashenfelter, and David E. Card (eds.), Handbook of Labor Economics, Volume 3A, Rotterdam: Elsevier, 1801-1863.

Chevalier, Arnaud, Colm Harmon, Ian Walker and Yu Zhu (2004). 'Does Education Raise Productivity, or Just Reflect it?’, Economic Journal 114, 499-517.

Co, Catherine Y., Ira N. Gang and Myeong-Su Yun (2005). 'Self-Employment and Wage Earning in Hungary', Review of Development Economics 9(2), 150-165.

Cobb-Clark, Deborah A. and Stefanie Schurer (2011). 'Two Economists' Musings on the Stability of Locus of Control', IZA Discussion Paper 5630, Institute for the Study of Labor.

Cobb-Clark, Deborah A. and Stefanie Schurer (2012). 'The Stability of Big-Five Personality Traits', Economics Letters 115(1), 11-15.

Costa, Paul T. and Robert R. McCrae (1992). Revised NEO Personality Inventory (NEO-PI-

R) and NEO Five Factor Inventory (NEO-FFI) Professional Manual, Odessa, FL: Psychological Assessment Resources.

Cramer, J. S., Joop Hartog, Nicole Jonker, and C. Mirjam Van Praag (2002). 'Low Risk Aversion Encourages the Choice for Entrepreneurship: An Empirical Test of a Truism', Journal of Economic Behavior and Organization 48(1), 29-36.

Dickson, Matt and Colm Harmon (2011). 'Economic Returns to Education: What We Know, What We Don’t Know, and Where We Are Going — Some Brief Pointers', Economics of Education Review 30, 1118- 1122.

Dohmen, Thomas, Armin Falk, David Huffman, Uwe Sunde, Jürgen Schupp and Gert G. Wagner (2011). 'Individual Risk Attitudes: Measurement, Determinants, and Behavioral Consequences', Journal of the European Economic Association 9(3), 522-550.

Doms, Mark, Ethan Lewis and Alicia Robb (2010). 'Local labor force education, new business characteristics, and firm performance’, Journal of Urban Economics 67, 61-77.

Douhan, Robin and C. Mirjam Van Praag (2009). 'Entrepreneurship, Wage Employment and Control in an Occupational Choice Framework', IZA Discussion Paper 4211, Institute for the Study of Labor.

Evans, David S. and Linda S. Leighton (1989). 'Some Empirical Aspects of Entrepreneurship', American Economic Review 79(3), 519-535.

Fairlie, Robert W. and Alicia Robb (2007). 'Families, Human Capital, and Small Business: Evidence from the Characteristics of Business Owners Survey', Industrial and Labor Relations Review 60(2), 225-245. 
Global Entrepreneurship Research Association (2012),

http://www.google.com/publicdata/explore?ds=k6n6dkler1898_\&ctype=l\&strail=false\&b

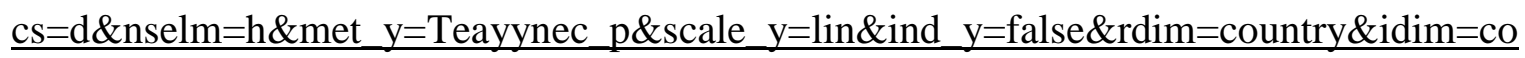
untry:DE:US\&ifdim=country\&tstart $=989190000000 \&$ tend $=1304722800000 \&$ hl $=$ en_US

\&dl=en_US\&ind=false (last accessed: 6 August 2012).

Harmon, Colm, Hessel Oosterbeek and Ian Walker (2003). 'The Returns to Education: Microeconomics', Journal of Economic Surveys 17(2), 115-156.

Hartog, Joop and Hessel Oosterbeek (2007). 'What should you know about private returns to education?’, in: Joop Hartog and Henriëtte Maassen Van den Brink (eds.), Human Capital: Moving the Frontier, Cambridge: Cambridge University Press, 7-20.

Hausman, Jerry A. (1978). 'Specification Tests in Econometrics', Econometrica 46(6), 125171.

Heckman, James J. (1979). 'Sample Selection Bias as a Specification Error', Econometrica 47(1), 153-161.

Heineck, Guido and Silke Anger (2010). 'The Returns to Cognitive Abilities and Personality Traits in Germany', Labour Economics, 17(3), 535-546.

Henderson, Daniel J., Solomon W. Polachek and Le Wang (2011). 'Heterogeneity in schooling rates of return’ Economics of Education Review 30(6), 1202-1214.

Heywood, John S. and Xiangdong Wei (2004). 'Education and Signaling: Evidence from a Highly Competitive Labor Market’, Education Economics 12(1), 1-16.

Hinz, Thomas and Monika Jungbauer-Gans (1999). 'Starting a Business after Unemployment: Characteristics and Chances of Success (Empirical Evidence from a Regional German Labour Market)', Entrepreneurship and Regional Development 11, 317-333.

Hoogerheide, Lennart, Joern H. Block and Roy Thurik (2012). 'Family Background Variables as Instruments for Education in Income Regressions: A Bayesian Analysis', Economics of Education Review 31, 515-523.

Hvide, Hans K. (2009). 'The Quality of Entrepreneurs’, Economic Journal 119, 1010-1035.

Kelley, Donna J., Slavica Singer and Mike Herrington (2011). 'The Global Entrepreneurship Monitor, 2011 Global Report’, Babson College, Universidad del Desarrollo and Universiti Tun Abdul Razak.

Lazear, Edward P. (2004). 'Balanced Skills and Entrepreneurship', American Economic Review 94(2), 208-211.

Lazear, Edward P. (2009). 'Firm-specific Human Capital: A Skill-Weights Approach', Journal of Political Economy 117(5), 914-940. 
Lee, Lung-Fei (1983). 'Generalized econometric models with selectivity’, Econometrica 51(2), 507-512.

Levin, Jesse and Erik Plug (1999). 'Instrumenting Education and the Returns to Schooling in the Netherlands', Labour Economics 6(4), 521-534.

Mincer, Jacob (1974). Schooling, Experience and Earnings, New York: Columbia University Press.

Michelacci, Claudio (2002). 'Low Returns in R\&D Due to the Lack of Entrepreneurial Skills’, Economic Journal 113(484), 207-225.

Neal, Derek (1995). 'Industry-specific Human Capital: Evidence from Displaced Workers', Journal of Labor Economics 13(4), 653-677.

Parker, Simon C. (1997). 'The Distribution of Self-employment Income in the United Kingdom, 1976-1991', Economic Journal 107, 455-466.

Parker, Simon C., Yacine Belghitar and Tim Barmby (2005). 'Wage Uncertainty and the Labour Supply of Self-employed Workers’, Economic Journal 115, C190-C207.

Parker, Simon C. and C. Mirjam Van Praag (2006). 'Schooling, capital constraints and entrepreneurial performance: the endogenous triangle', Journal of Business and Economic Statistics 24(4), 416-431.

Reich, B. Robert (2010). 'Entrepreneur or Unemployed?', New York Times, New York edition, June 2nd.

Reynolds, Paul D., William D. Bygrave, Erkko Autio, Larry W. Cox and Michael Hay (2002). 'Global Entrepreneurship Monitor 2002, Executive Report', Babson College, Ewing Marion Kauffman Foundation and London Business School.

Riley, John G. (2001). 'Silver Signals: Twenty-five Years of Screening and Signalling', Journal of Economic Literature 39, 432-78.

Rotter, Julian B. (1966). 'Generalized Expectancies for Internal versus External Control of Reinforcement', Psychological Monographs 80, 1-2.

Schultz, Theodore (1963). The Economic Value of Education, New York: Columbia University Press.

Shane, Scott (2006). 'Introduction to the Focused Issue on Entrepreneurship', Management Science 52, 155-159.

Sternberg, Rolf, Udo Brixy and Jan-Florian Schlapfner (2006). 'Global Entrepreneurship Monitor, Länderbericht Deutschland 2005’ (Country Report Germany 2005), University of Hanover and Institute for Employment Research (IAB), Nuremberg. 
Spence, Michael (1973). ‘Job Market Signalling’, Quarterly Journal of Economics 87, 355373.

Taylor, Mark P. (1996). 'Earnings, Independence or Unemployment: Why Become SelfEmployed?’, Oxford Bulletin of Economics and Statistics 52(2), 253-265.

Taylor, Mark P. (1999). 'Survival of the Fittest? An Analysis of Self-employment Duration in Britain’, Economic Journal 109, C140-C155.

Taylor, Mark P. (2001). 'Self-employment and Windfall Gains in Britain: Evidence from Panel Data,' Economica 68(272), 539-65.

Van der Sluis, Justin, C. Mirjam Van Praag and Wim Vijverberg (2008). 'Education and Entrepreneurship Selection and Performance: A Review of the Empirical Literature', Journal of Economic Surveys, 22(5), pp. 795-841.

Van Praag, C. Mirjam and Peter H. Versloot (2007). 'What is the Value of Entrepreneurship?

A Review of Recent Research', Small Business Economics 29, 351-382.

Van Praag, C. Mirjam, Arjen Van Witteloostuijn and Justin Van der Sluis (2009). 'Returns for

Entrepreneurs vs. Employees: The Effect of Education and Personal Control on the Relative Performance of Entrepreneurs vs. Wage Employees', IZA Discussion Paper 4628, Institute for the Study of Labor.

Wagner, Joachim (2005). ' Der Noth gehorchend, nicht dem eigenen Trieb' — Nascent Necessity and Opportunity Entrepreneurs in Germany: Evidence from the Regional Entrepreneurship Monitor (REM)', IZA Discussion Paper 1608, Institute for the Study of Labor.

Wagner, Gert G., Joachim R. Frick and Jürgen Schupp (2007). 'The German Socio-Economic Panel Study (SOEP). Scope, Evolution and Enhancements', Journal of Applied Social Science Studies, 127(1), 139-170.

Williams, Donald R. (2003). 'Returns to Education and Experience in Self-Employment: Evidence from Germany’, Journal of Applied Social Science Studies 123(1), 139-150.

Wolpin, Kenneth I. (1977). 'Education and Screening', American Economic Review 67, 949958.

Wooldridge, Jeffrey (2002). 'Econometric Analysis of Cross Section and Panel Data', London: MIT Press.

Zhao, Hao and Scott E. Seibert (2006). 'The Big Five Personality Dimensions and Entrepreneurial Status: A Meta-Analytical Review', Journal of Applied Psychology 91(2), 259-271. 


\section{Appendix}

\section{Table A 1: Description of variables}

\begin{tabular}{|c|c|}
\hline Variable & Description \\
\hline oppEntre & Dummy for a person who is classified as an opportunity entrepreneur. \\
\hline necEntre & Dummy for a person who is classified as a necessity entrepreneur. \\
\hline selfempl & Dummy for a self-employed person (sum of opportunity and necessity entrepreneurs). \\
\hline grossEarnings & Gross (before-tax) earnings per actual hours worked (in Euro). \\
\hline educ & Number of years in formal education, generated based on educational degrees. \\
\hline workExp $^{\mathrm{a}}$ & Experience in full- and part-time work prior to the year of observation (in years). \\
\hline unemplExp ${ }^{a}$ & Accumulated duration of unemployment prior to the year of observation (in years). \\
\hline age & Age of person (in years). \\
\hline female & Dummy for females. \\
\hline west & $\begin{array}{l}\text { Dummy for a person living in western Germany (i.e. the old member states of former } \\
\text { West Germany). }\end{array}$ \\
\hline partner & Dummy for a person living with a partner (married or unmarried). \\
\hline children & Dummy for a person with at least one child less than 17 years old in the household. \\
\hline handicapped & Dummy for a physically or mentally challenged person. \\
\hline migrant & Dummy for a person with a migration background. \\
\hline openness & Openness to experience (scale 1-7). \\
\hline conscientiousness & Conscientiousness (scale 1-7). \\
\hline extraversion & Extraversion (scale 1-7). \\
\hline agreeableness & Agreeableness (scale 1-7). \\
\hline neuroticism & Neuroticism, i.e. the opposite of emotional stability (scale 1-7). \\
\hline internal locus & Internal locus of control (scale 1-7). \\
\hline external locus & External locus of control (scale 1-7). \\
\hline risk tolerance & General willingness to take risks (scale 0-10). \\
\hline father selfempl & $\begin{array}{l}\text { Dummy for a person whose father was self-employed when the respondent was } 15 \text { years } \\
\text { old. }\end{array}$ \\
\hline father's educ & Father's number of years in formal education, generated based on educational degrees. \\
\hline mother's educ & Mother's number of years in formal education. \\
\hline childrenBelow6 & Number of children below 6 years of age in the household. \\
\hline occTrainedFor & Dummy for a person who works in an occupation she was trained for. \\
\hline employsWorkers & Dummy for a self-employed person who has at least one employee. \\
\hline libProfessional & $\begin{array}{l}\text { Dummy for a self-employed liberal professional (physicians, lawyers, architects, } \\
\text { journalists, artists, etc.). }\end{array}$ \\
\hline hoursWorked & Hours usually worked per week including overtime work. \\
\hline Year dummies & Dummies for the years $1999-2010$. \\
\hline
\end{tabular}


Table A 2: Descriptive statistics for the specific definition of entrepreneurial types

\begin{tabular}{|c|c|c|c|c|c|c|c|}
\hline & \multirow{2}{*}{\multicolumn{2}{|c|}{$\begin{array}{l}\text { Opportunity } \\
\text { entrepreneurs (OE) }\end{array}$}} & \multirow{2}{*}{\multicolumn{2}{|c|}{$\begin{array}{l}\text { Necessity } \\
\text { entrepreneurs (NE) }\end{array}$}} & \multicolumn{3}{|c|}{$t$-tests of equal means } \\
\hline & & & & & OE vs E & NE vs E & OE vs NE \\
\hline & Mean & Std dev. & Mean & Std dev. & $p$-value & $p$-value & $p$-value \\
\hline grossEarnings & 18.83 & 14.17 & 15.06 & 18.57 & 0.00 & 0.21 & 0.00 \\
\hline educ & 13.70 & 2.98 & 13.44 & 2.81 & 0.00 & 0.00 & 0.06 \\
\hline workExp & 17.93 & 9.07 & 19.19 & 9.32 & 0.00 & 0.00 & 0.00 \\
\hline unemplExp & 0.14 & 0.62 & 0.48 & 1.24 & 0.00 & 0.00 & 0.00 \\
\hline age & 42.57 & 8.84 & 44.36 & 8.97 & 0.00 & 0.00 & 0.00 \\
\hline female & 0.30 & 0.46 & 0.31 & 0.46 & 0.00 & 0.00 & 0.73 \\
\hline west & 0.82 & 0.38 & 0.51 & 0.50 & 0.00 & 0.00 & 0.00 \\
\hline partner & 0.77 & 0.42 & 0.79 & 0.41 & 0.99 & 0.15 & 0.26 \\
\hline children & 0.44 & 0.50 & 0.36 & 0.48 & 0.00 & 0.34 & 0.00 \\
\hline handicapped & 0.04 & 0.19 & 0.05 & 0.22 & 0.00 & 0.64 & 0.18 \\
\hline migrant & 0.09 & 0.29 & 0.10 & 0.30 & 0.00 & 0.03 & 0.63 \\
\hline openness & 4.76 & 1.09 & 4.88 & 1.05 & 0.00 & 0.00 & 0.02 \\
\hline conscientiousness & 6.05 & 0.89 & 5.89 & 0.94 & 0.03 & 0.00 & 0.00 \\
\hline extraversion & 5.08 & 1.05 & 5.10 & 1.03 & 0.00 & 0.00 & 0.69 \\
\hline agreeableness & 5.30 & 0.96 & 5.34 & 0.97 & 0.00 & 0.12 & 0.45 \\
\hline neuroticism & 3.73 & 1.09 & 3.68 & 1.15 & 0.00 & 0.00 & 0.38 \\
\hline internal locus & 6.03 & 0.81 & 5.95 & 0.81 & 0.00 & 0.00 & 0.02 \\
\hline external locus & 3.33 & 0.90 & 3.64 & 0.95 & 0.00 & 0.54 & 0.00 \\
\hline risk tolerance & 5.76 & 2.15 & 5.54 & 2.03 & 0.00 & 0.00 & 0.03 \\
\hline father selfempl & 0.11 & 0.32 & 0.07 & 0.25 & 0.00 & 0.69 & 0.00 \\
\hline father's educ & 12.13 & 2.88 & 12.02 & 2.93 & 0.00 & 0.00 & 0.40 \\
\hline mother's educ & 10.96 & 2.20 & 11.26 & 2.51 & 0.00 & 0.00 & 0.01 \\
\hline childrenBelow6 & 0.23 & 0.51 & 0.18 & 0.47 & 0.00 & 0.66 & 0.02 \\
\hline occTrainedFor & 0.69 & 0.46 & 0.58 & 0.49 & 0.00 & 0.00 & 0.00 \\
\hline employsWorkers & 0.50 & 0.49 & 0.34 & 0.47 & 0.00 & 0.00 & 0.00 \\
\hline libProfessional & 0.36 & 0.48 & 0.25 & 0.44 & 0.00 & 0.00 & 0.00 \\
\hline hoursWorked & 47.89 & 16.46 & 46.25 & 15.85 & 0.00 & 0.00 & 0.03 \\
\hline Person-year obs. & 1278 & & 705 & & & & \\
\hline
\end{tabular}

